\title{
Vitamin D and the skin: Physiology and pathophysiology
}

\author{
Daniel D. Bikle \\ Veterans Affairs Medical Center/University of California, San Francisco, 4150 Clement St (111N), \\ San Francisco, CA 94121, USA daniel.bikle@ucsf.edu
}

\begin{abstract}
The keratinocytes of the skin are unique in being not only the primary source of vitamin $\mathrm{D}$ for the body, but in possessing both the enzymatic machinery to metabolize the vitamin $\mathrm{D}$ produced to active metabolites (in particular $1,25(\mathrm{OH})_{2} \mathrm{D}$ ) and the vitamin D receptor (VDR) that enables the keratinocytes to respond to the $1,25(\mathrm{OH})_{2} \mathrm{D}$ thus generated. Numerous functions of the skin are regulated by vitamin $\mathrm{D}$ and/or its receptor. These include inhibition of proliferation, stimulation of differentiation including formation of the permeability barrier, promotion of innate immunity, regulation of the hair follicle cycle, and suppression of tumor formation. Regulation of these actions is exerted by a number of different coregulator complexes including the coactivators

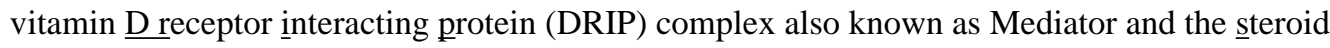
receptor coactivator (SRC) family (of which SRC 2 and 3 are found in keratincytes), the inhibitor hairless (Hr), and $\beta$-catenin whose impact on VDR function is complex. Different coregulators appear to be involved in different VDR regulated functions. This review will examine the various functions of vitamin $\mathrm{D}$ and its receptor in the skin, and explore the mechanisms by which these functions are regulated.
\end{abstract}

\section{Keywords}

Vitamin D; Epidermis; Hair follicle; Co-regulators; Differentiation; Carcinogenesis

\section{Introduction}

The epidermis is the major source of vitamin $\mathrm{D}$ for the body. Under the influence of sunlight (ultraviolet radiation, action spectrum 280-320nM or UVB) 7-dehydrocholesterol in the epidermis is converted to vitamin D. Moreover, the major cell of the epidermis, the keratinocyte, also possesses the enzymes (CYP27A1, the 25-hydroxylase, and CYP27 B1, the 1-hydroxylase) to further metabolize vitamin $\mathrm{D}$ to its active form 1,25 dihydroxyvitamin $\mathrm{D}\left(1,25(\mathrm{OH})_{2} \mathrm{D}\right)$. Like most other cells, the keratinocytes also express the vitamin D receptor (VDR) and so are capable of responding to the $1,25(\mathrm{OH})_{2} \mathrm{D}$ produced [1]. The relative importance of endogenous $1,25(\mathrm{OH})_{2} \mathrm{D}$ production relative to circulating $1,25(\mathrm{OH})_{2} \mathrm{D}$ is not clear. $1,25(\mathrm{OH})_{2} \mathrm{D}$, acting through the VDR, regulates proliferation in the basal layer (stratum basale) of the epidermis and promotes the sequential differentiation of keratinocytes as they form the upper layers of the epidermis. Loss of VDR or loss of the capacity to produce $1,25(\mathrm{OH})_{2} \mathrm{D}$ (CYP27B1 mutations/deletion) disrupts differentiation of the epidermis and results in hyperproliferation of the basal layers with disrupted function of the differentiated layers including permeability barrier formation and the innate immune response. The keratinocytes lining the outer layer of the hair follicle (the outer root sheath or ORS) also possess VDR. Loss of VDR function either by inactivating mutations or

(C) Springer Science+Business Media, LLC 2011

Correspondence to: Daniel D. Bikle. 
bioengineered deletions leads to loss of hair follicle cycling and alopecia. In this case, it is less obvious that the VDR requires $1,25(\mathrm{OH})_{2} \mathrm{D}$ for its activity in that deletion of CYP27B1 does not produce alopecia. Whether regulation of hair follicle cycling is truly a ligand independent action of VDR or whether an as yet to be identified other ligand is required is unclear. VDR also functions as a tumor suppressor. Mice lacking the VDR are susceptible to tumor formation in the skin induced either by chemical means or by UVR. As for hair follicle cycling, the role of $1,25(\mathrm{OH})_{2} \mathrm{D}$ in this tumor suppressor function is not clear as CYP27B1 null mice do not appear to be more susceptible to tumor formation by chemical means or UVB, although some studies support a protective role for $1,25(\mathrm{OH})_{2} \mathrm{D}$ topically applied. The specificity of VDR action within the skin for the different functions it regulates is attributed at least in part to the different coregulators that modulate its genomic actions. In the proliferating keratinocytes of the epidermis and hair follicle, the DRIP complex is the dominant coregulator. In the more differentiated keratinocytes of the epidermis, the SRC complexes (SRC 2 and 3) dominate VDR function. The role of $\mathrm{Hr}$ is less clear. For $1,25(\mathrm{OH})_{2} \mathrm{D}$ regulated VDR actions in epidermal keratinocytes, $\mathrm{Hr}$ acts as a cosuppressor. But its role in regulating hair follicle cycling, a 1,25 $(\mathrm{OH})_{2} \mathrm{D}$ independent action of VDR, indicates that both $\mathrm{Hr}$ and VDR are required suggesting a more complex role. In this review we will examine these different actions of vitamin $\mathrm{D}$ and its receptor, emphasizing the many roles vitamin D plays in regulating epidermal proliferation and differentiation, hair follicle cycling, and tumorigenesis.

\section{Vitamin D and calcium regulation of epidermal proliferation and differentiation}

The epidermis is composed of four layers of keratinocytes at different stages of differentiation (Fig. 1). The basal layer (stratum basale, SB) rests on the basal lamina separating the dermis and epidermis. Within this layer are the stem cells. These cells proliferate, providing the cells for the upper differentiating layers. They contain an extensive keratin network comprised of keratins K5 and K14. As the cells migrate upward from this basal layer they acquire the characteristics of a fully differentiated corneocyte, which is eventually sloughed off. The layer above the basal cells is the spinous layer (stratum spinosum, SS). These cells initiate the production of the keratins K1 and K10, which are the keratins characteristic of the more differentiated layers of the epidermis. Cornified envelope precursors such as involucrin also appear in the spinous layer as does the enzyme transglutaminase $\mathrm{K}$, responsible for the $\varepsilon$-( $\gamma$-glutamyl)lysine cross-linking of these substrates into the insoluble cornified envelope. The granular layer (stratum granulosum,SG), lying above the spinous layer, is characterized by electron-dense keratohyalin granules containing profilaggrin, the precursor of filaggrin, a protein thought to facilitate the aggregation of keratin filaments, and loricrin, a major component of the cornified envelope. Filaggrin, when metabolized to smaller fragments, is also thought to contribute to the hydration of the permeability barrier, and mutations of filaggrin are frequently found in patients with atopic dermatitis. The granular layer also contains lamellar bodies, lipid-filled structures that fuse with the plasma membrane, divesting their contents into the extracellular space between the SG and stratum corneum (SC) where the lipid contributes to the permeability barrier of skin. As the cells pass from the granular layer to the cornified layer (SC), they undergo destruction of their organelles with further maturation of the cornified envelope into an insoluble, highly resistant structure surrounding the keratin-filaggrin complex and linked to the extracellular lipid milieu. The outer layer of the epidermis provides not only a barrier to water loss (permeability barrier) but a barrier to invasion by infectious organisms via its expression of the innate immune system. In particular disruption of the barrier triggers the induction of defensins such as cathelicidin that provide the initial defense in killing such organisms. 
The role of calcium in epidermal differentiation is critical (Fig. 2). If keratinocytes are grown at calcium concentrations below $0.07 \mathrm{mM}$, they continue to proliferate but fail or are slow to develop intercellular contacts, stratify little if at all, and fail or are slow to form cornified envelopes. Acutely increasing the extracellular calcium concentration (Cao) above $0.1 \mathrm{mM}$ (calcium switch) leads to the rapid redistribution of a number of proteins from the cytosol to the membrane where they participate in the formation of intercellular contacts. These include the calcium receptor (CaR), phospholipase C- $\gamma 1$ (PLC- $\gamma 1$ ), src kinases, and the formation of the E-cadherin complex with phosphatidyl inositol 3 kinase (PI3K), various catenins including $\beta$-catenin, and phosphatidyl inositol 4-phosphate 5-kinase 1a (PIP5K1a), all of which play important roles in calcium induced differentiation [2-7]. These early events are accompanied by a rearrangement of actin filaments from a perinuclear to a radial pattern, which if disrupted blocks the redistribution of these proteins and blocks the differentiation process. Within hours of the calcium switch the keratinocytes begin making keratins K1 and K10 [8] followed, subsequently, by increased levels of profilaggrin (the precursor of filaggrin), involucrin, and loricrin $[8,9]$. As noted above loricrin, involucrin, and other proteins are cross linked into the insoluble cornified envelope by the calcium sensitive membrane bound form of transglutaminase (TG) $[9,10]$, which like involucrin and loricrin increases within $24 \mathrm{~h}$ after the calcium switch [11]. The relevance of these in vitro studies to the in vivo situation is indicated by the steep gradient of calcium within the epidermis with highest levels in the uppermost (most differentiated) layers [12].

The $\mathrm{CaR}$ is essential for these responses to calcium $[4,13]$. The $\mathrm{CaR}$ is a seven transmembrane domain, $\mathrm{G}$ protein coupled receptor first identified in parathyroid cells [14], that we cloned from keratinocytes [15]. We then developed a mouse in which the entire transmembrane domain and intracellular portion of the $\mathrm{CaR}$ is floxed enabling its deletion in keratinocytes (and other cells) [4, 16], and have used this model to demonstrate in vivo the role of $\mathrm{CaR}$ in calcium signaling within the keratinocyte, and its importance in differentiation [4].

The expression of the CaR is increased by $1,25(\mathrm{OH})_{2} \mathrm{D}_{3}$, making the keratinocyte more sensitive to the prodifferentiating actions of calcium [17]. All of the PLC family members are induced by $1,25(\mathrm{OH})_{2} \mathrm{D}_{3}[18]$ as they are by calcium [19], and blocking PLC- $\gamma 1$ expression prevents both $1,25(\mathrm{OH})_{2} \mathrm{D}_{3}$ and calcium stimulated differentiation [19, 20]. Calcium and $1,25(\mathrm{OH})_{2} \mathrm{D}_{3}$ also interact in their ability to induce involucrin and transglutaminase [21]. At least one explanation for the synergism in the induction of involucrin is that the calcium response element $(\mathrm{CaRE})$ and vitamin $\mathrm{D}$ response element (VDRE) in the involucrin promoter are quite close spatially [22, 23]. Mutations in the AP-1 site within the CaRE block both calcium and $1,25(\mathrm{OH})_{2} \mathrm{D}_{3}$ induction of the involucrin gene, but mutations of the VDRE block only its response to $1,25(\mathrm{OH})_{2} \mathrm{D}_{3}$.

As noted above the keratinocytes of the epidermis are unique in their ability to produce vitamin $\mathrm{D}_{3}$ from the precursor 7-dehydrocholesterol (7-DHC) and to convert the vitamin $\mathrm{D}$ produced to the active metabolite $1,25(\mathrm{OH})_{2} \mathrm{D} .1,25(\mathrm{OH})_{2} \mathrm{D}$ increases involucrin, transglutaminase activity, loricrin, filaggrin, PLC, CaR, and cornified envelope formation at subnanomolar concentrations [24-29] while inhibiting proliferation at least at concentrations above $1 \mathrm{nM}$. The antiproliferative effects are accompanied by a reduction in the expression of c-myc [30] and cyclin D1 [31] and an increase in the cell cycle inhibitors p2 $1^{\text {cip }}$ and p2 $7^{\mathrm{kip}}$. In addition, $1,25(\mathrm{OH})_{2} \mathrm{D}$ and its receptor regulate the processing of the long chain glycosylceramides that are critical for permeability barrier formation [32] and induce the receptors, toll like receptor 2 (TLR2) and its coreceptor CD14, that initiate the innate immune response in skin[33]. Activation of these receptors leads to the induction of CYP27B1 (the enzyme that produces $1,25(\mathrm{OH})_{2} \mathrm{D}$ ), which in turn induces cathelicidin 
resulting in the killing of invasive organisms[33,34]. As will be discussed subsequently, these functions are differentially regulated by different coactivators.

Although the most striking feature of the VDR-null mouse is the development of alopecia $[35,36]$ (also found in many patients with mutations in the VDR referred to as hereditary vitamin D resistance [37], these mice also exhibit a defect in epidermal differentiation as shown by reduced levels of involucrin and loricrin and loss of keratohyalin granules [38, 39]. Furthermore, these mice show a reduction in the lipid content of the lamellar bodies concomitant with a reduction in glucosylceramide production and transport into the lamellar bodies leading to a defective permeability barrier [32]. However, not all genes thought to be markers of differentiation are reduced in VDR null mice. In particular caspase 14 and filaggrin expression is increased [40]. The CYP27B1 null mouse also shows a reduction in levels of the epidermal differentiation markers and altered permeability barrier [41]. Furthermore, these mice have a blunted response to wounding with respect to induction of the innate immune response [33] and reduced ability to control skin infections [42]. However, as noted above the CYP27B1 null mice do not have a defect in hair follicle cycling.

The surprising failure of CYP27B1 null mice to reproduce the skin phenotype of VDR null mice raises the question of whether an alternative ligand is involved. The bile acid lithocholic acid has been identified as an alternative ligand for VDR [43] and found to stimulate cathelicidin and CYP24A in keratinocytes like $1,25(\mathrm{OH})_{2} \mathrm{D}$ [44]. However, it is unlikely that keratinocytes produce LCA at the concentrations required $(10 \mu \mathrm{M})$. On the other hand 20-hydroxyvitamin $\mathrm{D}$, a product of vitamin $\mathrm{D}$ that could be produced in the skin in adequate concentrations does appear to inhibit proliferation and stimulate differentiation in a VDR dependent fashion similar to $1,25(\mathrm{OH})_{2} \mathrm{D}$ [45]. Whether this vitamin $\mathrm{D}$ metabolite is involved in hair follicle cycling remains to be demonstrated.

\section{Role of VDR coregulators in epidermal proliferation and differentiation Role of DRIP and SRC as VDR coregulators}

The process of epidermal differentiation is sequential. $1,25(\mathrm{OH})_{2} \mathrm{D}$ and VDR regulate all steps from the control of proliferation in the SB, to the regulation of $\mathrm{K} 1, \mathrm{~K} 10$, involucrin, and transglutaminase production in the SS, to the regulation of loricrin and filaggrin production in the SG, to the synthesis of lipids required for the permeability barrier in the SC, and to the development of the innate immune system [1, 29, 33]. How does this occur? Although CYP27B1 and VDR are found in highest concentration in the SB, they are both distributed throughout the epidermis [46-48], so this does not provide an obvious explanation for the sequential induction of genes involved in the differentiation process. However, VDR requires the binding of coactivators to stimulate transcription. As mentioned above, the two major coactivator complexes in the epidermis are DRIP (Mediator) and SRC $[49,50]$. An important clue for understanding the sequential induction of epidermal differentiation by $1,25(\mathrm{OH})_{2} \mathrm{D}$ and VDR came from the demonstration that in proliferating keratinocytes DRIP dominated the binding to VDR, whereas SRC dominated VDR binding in differentiated keratinocytes [49, 51]. Furthermore, DRIP205 (Med1) is expressed in highest concentration in the SB and SS, whereas SRC3 is expressed in highest concentration in the SG [52]. The DRIP complex is anchored to VDR via DRIP205 [53, 54]. The SRC complex is anchored to VDR with one of three homologous proteins, SRC1, 2, and 3[55], but only SRC2 and 3 are found in keratinocytes [49]. These coactivator complexes interact with the $\mathrm{C}$ terminal (AF2) domain of VDR following ligand binding via LxxLL motifs (NR boxes). They do not bind to VDR at the same time, competing as they do for the same region of the VDR [54]. The SRC coactivators have 3 NR boxes, whereas DRIP205 has 2. VDR binds most strongly to the 2nd and 3rd NR box of SRC1 and 2, the 3rd NR box of 
SRC3, and the 2nd NR box of DRIP205 [56]. Different nuclear hormone receptors differ in the affinity for the different NR boxes of the different coactivators suggesting some degree of specificity [57]. SRC recruits CREB-binding protein (CBP) or P300 and other histone acetyl transferases (HATs) and methyltranferases (MeTs) to the VDR resulting in a multisubunit complex [58]. The HAT and MeT activity of the SRC complex is thought to destabilize the interaction between DNA and the histone core, enabling transcription to occur. The DRIP complex does not have HATor MeTactivity but functions, at least in part, through recruitment of RNA polymerase II to the transcription start site [54, 59]. Some studies suggest that the order of coactivator binding to its nuclear hormone receptor is sequential with different kinetics, generally with SRC binding preceding and being required for DRIP binding [57]. Other studies indicate that the specificity of coactivator binding to VDR depends on the gene being regulated [60,61], the ligand being evaluated [62], and the cellular context $[63,64]$. In the keratinocyte, the sequential action of $1,25(\mathrm{OH})_{2} \mathrm{D}$ and its receptor on keratinocyte differentiation appears to be due to the differential expression and distribution of these coactivators according to the differentiation status of the cell coupled with the selectivity of genes regulated by VDR for one or the other of the coactivator complexes [29, 49, 51, 65].

DRIP205 is expressed in proliferating keratinocytes, and its expression decreases with differentiation, as the expression of SRC3 is increased [49]. Knockdown of DRIP205 using siRNA results in increased keratinocyte proliferation, similar to that seen by knocking down VDR itself, but knockdown of SRC3 does not show such an effect [51]. Inhibition of DRIP205 binding to VDR in proliferating keratinocytes blocks VDR transcriptional activity with a VDRE reporter construct, but such inhibition is not seen in differentiated keratinocytes [49]. However, this inhibition of transcriptional activity turns out to be gene specific. For example, knockdown of DRIP205 using siRNA methodology has a greater impact on keratins 1, 10, and involucrin expression than does knockdown of SRC3, although depletion of both coactivators profoundly reduces loricrin and filaggrin expression [29]. On the other hand SRC3 knockdown, not DRIP205 knockdown, reduces glucosylceramide production and lamellar body formation similar to that of VDR knockdown [32], and prevents $1,25(\mathrm{OH})_{2} \mathrm{D}$ induced cathelicidin expression [52]. In initial studies with mice in which either DRIP205 or SRC3 is deleted specifically in keratinocytes we have found that the phenotypes are quite different with the DRIP 205 null showing hyperproliferation of the epidermis and disruption of hair follicle cycling similar to the VDR null mouse but unlike the SRC3 null mouse, whereas the SRC3 null mouse demonstrates abnormalities in permeability barrier formation and the innate immune response [66]. Thus, SRC appears to facilitate the ability of VDR to regulate the more differentiated functions of the keratinocyte, whereas DRIP facilitates the ability of VDR to regulate proliferation and hair follicle cycling, although some overlap in coactivator function is observed. However, in interpreting these data, it must be remembered that these coactivators regulate a number of other nuclear hormone receptors and transcription factors, changes in function of which likely contribute to the phenotypes observed.

\section{Role of hairless as VDR coregulator}

Although $\mathrm{Hr}$ has been mostly studied for its critical role in hair follicle cycling, like VDR it is expressed in the nuclei of keratinocytes in the stratum basale as well as the outer root sheath (ORS) of the hair follicle [39]. However, we found little or no VDR in the inner root sheath (IRS) and hair bulb or cells of the dermal papilla and connective tissue sheath (CTS), whereas we did find $\mathrm{Hr}$ in those locations [39]. However, another study with a different $\mathrm{Hr}$ antibody showed a somewhat more restricted distribution (ORS and hair bulb) [67]. Hr has characteristics of a coregulator in that it resides in the nucleus; its structure contains a nuclear localization signal, a putative zinc finger, and three LXXLL motifs [68] like that 
found in coactivators that interact with nuclear hormone receptors such as VDR as well as ФХХФФ motifs ( $\Phi$ =hydrophobic amino acid) similar to regions in corepressors like SMRT and NCoR responsible for the binding of these corepressors to nuclear hormone receptors. Recent data suggest that $\mathrm{Hr}$ may function as a histone demethylase [69]. In the brain, $\mathrm{Hr}$ has been suggested as a corepressor of the thyroid receptor (THRb) in that $\mathrm{Hr}$ can bind to THRb and inhibit its transcriptional activity [70]. However, $\mathrm{Hr}$ does not appear to regulate thyroid hormone action in the keratinocyte [71]. Rather, VDR appears to be the target [72]. Hsieh et al. [73] demonstrated that $\mathrm{Hr}$ could bind to VDR in COS cells. They noted that Hr bound to VDR in the same region predicted for corepressor binding, and different from the $\mathrm{C}$-terminal region to which coactivators bind. The region of $\mathrm{Hr}$ responsible for VDR binding contains one LXXLL motif, but also a ФXXФФ motif. However, only mutations in the ФХХФФ motif altered binding to VDR [73]. Furthermore, when both motifs were tested separately

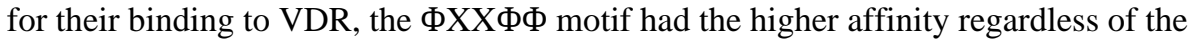
presence or absence of $1,25(\mathrm{OH})_{2} \mathrm{D}$ [56]. The endogenous VDR binds to endogenous $\mathrm{Hr}$ in keratinocytes [72]. In epidermal keratinocytes Hr blocks the ability of $1,25(\mathrm{OH})_{2} \mathrm{D}$ to induce genes such as involucrin, transglutaminase, phospholipase $\mathrm{C}-\gamma 1$ and stimulation of a CYP24A1 (24-hydroxylase) promoter construct containing the vitamin D response element (VDRE) of this vitamin D target gene, whereas inhibition of $\mathrm{Hr}$ expression enhances the stimulation by $1,25(\mathrm{OH})_{2} \mathrm{D}$ of these markers [72]. Antibodies to $\mathrm{Hr}$ enhance the binding of VDR to VDREs in vitamin D target genes in gel retardation assays [72] suggesting that $\mathrm{Hr}$ binding to VDR blocks its binding to VDREs. $1,25(\mathrm{OH})_{2} \mathrm{D}$ displaces $\mathrm{Hr}$ from VDREs as it recruits the coactivators DRIP205 and SRC3 to these same VDREs [72]. Thus at least for $1,25(\mathrm{OH})_{2} \mathrm{D}$ stimulated actions of $\mathrm{VDR}, \mathrm{Hr}$ is a corepressor. However, the $\mathrm{Hr}$ null mouse demonstrates upregulation of selected differentiation markers in the epidermis (caspase 14, filaggrin) [74], similar to that seen in the VDR null mouse [40]. These counter intuitive results suggest a dual role for $\mathrm{Hr}$ in the mechanisms by which vitamin $\mathrm{D}$ regulates epidermal differentiation (suppressing some functions but enabling others). This dual role will likewise be apparent in the subsequent discussion of Hr, VDR and hair follicle cycling.

\section{Role of $\beta$-catenin as VDR coregulator}

Wnt signaling via activation of $\beta$-catenin has a complex role in VDR function (Fig. 3). Wnt ligands bind to their seven-transmembrane Frizzled receptors and an LRP5 or LRP6 coreceptor leading to phosphorylation of disheveled (Dvl) resulting in disruption of the axin/ APC complex and inhibition of the kinase activity of glycogen synthase kinase $3 \beta$ (GSK-3 $\beta$ ). When active GSK-3 $\beta$ phosphorylates the serine(s) within exon 3 of $\beta$-catenin facilitating its degradation by the E3 ubiquitin ligase. Thus wnt signaling increases the availability of $\beta$-catenin in the nucleus, where it binds to transcription factors of the T-cell factor (TCF) and lymphoid enhancer factor (LEF) families to promote expression of genes such as cyclin D1 and c-myc [75] important for proliferation. $\beta$-catenin also forms part of the adherens junction complex with E-cadherin where it may play an important role in keratinocyte differentiation [6]. Tyrosine phosphorylation of E-cadherin, as occurs after calcium administration to keratinocytes, promotes the binding of $\beta$-catenin and other catenins to the adherens junction complex $[6,76]$ making it less available for transcriptional activity. Over expression and/or activating mutations in the $\beta$-catenin pathway lead to skin tumors, in this case pilomatricomas or trichofolliculomas (hair follicle tumors) [77-79] indicative of the hyperproliferative response to $\beta$-catenin in these cells. Activating mutations of specific serines within exon 3, or deletion of exon 3, block phosphorylation of $\beta$-catenin by GSK-3 $\beta$ keeping it active. In colon cancer cells VDR has been shown to bind to $\beta$ catenin, and reduce its transcriptional activity in a ligand dependent fashion [80]. Furthermore, in these cells $1,25(\mathrm{OH})_{2} \mathrm{D}$ has been shown to increase E-cadherin expression, such that $\beta$-catenin is redistributed from the nucleus to the plasma membrane where it forms a complex with E-cadherin and other catenins at adherens junctions [81]. We [82] have 
similar observations in keratinocytes. However, the suppression of $\beta$-catenin signaling by $1,25(\mathrm{OH})_{2} \mathrm{D}$ does not necessarily require E-cadherin [83]. Rather $\beta$-catenin binds to VDR in its AF-2 domain, binding that enhances the ability of $1,25(\mathrm{OH})_{2} \mathrm{D}$ to activate the transcriptional activity of the VDR [83] but blocks the transcriptional activity of $\beta$-catenin [82]. Mutations in the AF-2 domain that block coactivator binding do not necessarily block $\beta$-catenin binding [83]. Whether $\beta$-catenin binding alters DRIP205 or SRC3 binding to this same region has not been determined. Palmer et al. [84] evaluated the interaction between VDR and $\beta$-catenin in transcriptional regulation in keratinocytes, and identified putative response elements for VDR and $\beta$-catenin/LEF in a number of genes. These interactions were either positive or negative, depending on the gene being evaluated. The hypothesis put forward is that genes in which the interaction was positive (ie. stimulated transcription) benefited from $\beta$-catenin acting as a coactivator for VDR on VDREs, whereas in situations where the interaction was negative (ie. suppression of transcription) VDR prevented $\beta$ catenin from binding to TCF/LEF required for transcription in those genes. We [82] have found in keratinocytes that knockdown of VDR and DRIP205 reduces E-cadherin expression and formation of the $\beta$-catenin/E-cadherin membrane complex resulting in increased $\beta$-catenin transcriptional activity, whereas $1,25(\mathrm{OH})_{2} \mathrm{D}$ administration has the opposite effect. This was associated with increased (with VDR and DRIP205 knockdown) or decreased (with $1,25(\mathrm{OH})_{2} \mathrm{D}$ administration) keratinocyte proliferation and cyclin D1 expression, respectively. Other studies have demonstrated that VDR potentiates, not inhibits, $\beta$-catenin transcriptional activity. Cianferotti et al. [85] found a reduction in proliferation of keratinocytes in the dermal portion of the hair follicle (below the bulge) in VDR null mice, and no stimulation of proliferation when $\beta$-catenin was overexpressed in these cells in contrast to the stimulation of proliferation in control animals. Thus VDR/ $\beta$-catenin interactions can be positive or negative, and this depends on the gene/cell/function being evaluated.

\section{Role of VDR in hair follicle cycling}

The hair follicle cycle is divided into three main stages: anagen, catagen, and telogen (Fig. 4). Anagen is the stage of hair follicle growth; catagen is the stage of regression; telogen is the resting stage. Only the proximal or dermal portion of the hair follicle cycles; the distal or epidermal portion does not. The duration of these stages in a given species varies from location to location on the body and between genders. Furthermore, there are two types of cycles: developmental and adult. The developmental cycle is initiated during embryogenesis. The follicle develops from specific regions of the epidermis called placodes. The development, number and placement of these placodes are under the control of a number of factors to which we will return. The follicle is induced to grow by its interaction with a collection of specialized mesenchymal cells in the dermis called the dermal papilla. Wnt signaling ( $\beta$-catenin) appears to be necessary to maintain the ability of the dermal papilla to stimulate hair follicle growth [86, 87]. Following the developmental cycle, which leads to the initial coat of hair, the follicle undergoes repetitive cycling until senescence. The length of the hair is dependent on the duration of anagen. During this stage the follicle grows through the dermis into the subcutaneous tissue. As the follicle develops different cell layers appear. The outer root sheath (ORS) is a direct extension of the stratum basale, and separates the hair follicle from the surrounding connective tissue sheath (CTS). From outside in are found the companion layer, the three layers of the inner root sheath (IRS)-Henle's layer, Huxley's layer, cuticle of the IRS - and the hair shaft itself including the cuticle of the shaft, shaft cortex, and shaft medulla. Stem cells in the bulge are capable of generating all cells in the hair follicle and epidermis [88]. The keratins produced by the cells of the IRS and hair shaft differ from those expressed by epidermal keratinocytes [89]. Of particular interest is these hair keratins have $\beta$-catenin/lef1 binding sites in their promoters that regulate their expression [90]. Following anagen, the follicle enters catagen during which massive 
apoptosis occurs primarily in the cells of the proximal follicle (the dermal portion). At the end of catagen the follicle enters telogen, the resting phase. Duration of telogen is highly variable. However, most hair shafts remain attached to the follicle during telogen, maintaining the coat of hair throughout. A new cycle then begins with anagen. The juxtaposition of the dermal papilla to the bulge is critical for this process to begin, and it is associated with increased proliferation of stem cells in the bulge with migration of cells from the bulge into the hair bulb to restart the growth of the hair follicle. The regulatory elements that control the transition from one stage to the next are not well understood.

Alopecia is a well-known part of the phenotype of many patients with mutations in their VDR [91, 92], a syndrome currently known as hereditary vitamin D resistant rickets (HVDRR), and alopecia is part of the phenotype of the VDR null mouse [35, 36]. In that vitamin D deficiency per se or CYP27B1 mutations are not associated with alopecia, the explanation for this phenomenon has remained obscure. These mice develop their first coat of hair normally, but reinitiation of anagen following the first cycle or after depilation is impaired [93]. Reconstitution of the VDR to the VDR null mouse skin using a keratinocyte specific promoter reverses the defect in hair growth without reversing the metabolic defects of skeletal growth retardation, hypocalcemia, and rickets otherwise associated with the VDR null condition $[94,95]$. On the other hand, correction of the metabolic abnormalities with a high calcium diet prevents the rickets and hyperparathyroidism but does not prevent the alopecia [96]. Furthermore, it is the lack of VDR in the keratinocyte as opposed to the dermal papilla that is critical. Dermal papilla cells obtained from either VDR null or wildtype mice can initially induce hair growth in a hair reconstitution assay when mixed with epidermal keratinocytes obtained from wildtype or VDR null mice, but if the hair grown with keratinocytes from VDR null mice is then depilated, anagen will not be reinitiated regardless of the source of dermal papilla cells [93]. We [97] have confirmed this result by demonstrating that deletion of VDR specifically in keratinocytes leads to alopecia without any of the systemic changes seen in the global VDR null mouse.

Hr mutations in both mice [98] and humans $[99,100]$ and transcriptionally inactivating $\beta$ catenin mutations in mice $[103,104]$ result in phenocopies of the VDR null mouse and some human VDR mutations, respectively, with regard to the morphologic changes observed in hair follicle cycling. In these models the abnormality leading to alopecia develops during catagen at the end of the developmental cycle, precluding initiation of anagen in the first postnatal cycle. The dissociation of the dermal papilla from the hair bulb by the end of catagen is thought to account for the failure to initiate the subsequent anagen in both $\mathrm{Hr}$ mutant and VDR null mice $[39,98,103]$. Signaling via the hedgehog $(\mathrm{Hh})$ and wnt pathways appears to be important for these mesenchymal/epithelial interactions. Expression of Gli 1 and 2 (transcription factors activated by Hh) and LEF1 (transcription factor involved with $\beta$-catenin transcriptional activity) is reduced during the latter stages of catagen in both the Hr and VDR null hair follicle [40]. The distal (epidermal) portion of the hair follicle including the sebaceous gland as well as the interfollicular epidermis is less impacted [38, 98, 103, 104]. Indeed expression of Hh signaling pathway components is increased in the interfollicular epidermis and utricles of the VDR null mouse [82]. The large dermal cysts that develop with time contain markers of the differentiated interfollicular epidermis and sebaceous gland [38] suggesting their origin from the distal portion of the hair follicle or epidermis, features similar to that seen in $\mathrm{Hr}$ and $\beta$-catenin mutant animals [74, 103, 104].

The control of hair follicle development and cycling is complex [101, 102], and a large number of factors are implicated in this process. Many of these gene products are involved in placode and/or hair follicle development, and so their overexpression or underexpression results in abnormalities in the developmental cycle of hair growth. These are phenotypes 
different from that seen in the VDR null mouse. Sonic hedgehog (Shh) is one of these factors [105], but it appears to play an important role in adult hair follicle cycling as well. Disruption of canonical wnt signaling ( $\beta$-catenin or LEF1 mutations) disrupts both developmental and postnatal hair follicle cycling, and is associated with loss of Shh expression [101, 102]. Both Hr null [67] and VDR null mice show loss of Shh expression in the proximal (dermal) portion of the hair follicle [40]. The Hr null mouse shows an increase in expression of the wnt inhibitor WISE [67], whereas wnt4 is reduced in the VDR null hair follicle [40]. Wnt4 is normally expressed in the matrix and precortex, and would be expected to have an important role in interactions with the dermal papilla [106]. We have not seen a difference in $\beta$-catenin mRNA levels, but transcriptional activity of $\beta$-catenin is increased in VDR null mouse hair follicles as indicated by a TOPgal reporter (Teichert and Bikle, unpublished observations). As noted previously VDR has been found to bind to $\beta$ catenin directly, reducing its interaction with TCF4 or LEF1 and so reducing the transcriptional activity of $\beta$-catenin $[80,81,83]$. These results differ from those obtained by Cianferotti et al. [85], as noted earlier. Furthermore, Luderer et al. [107] demonstrated direct binding of the VDR to LEF1 in the absence of ligand, binding that required the DNA binding domain of the VDR, adding additional complexity to the interaction between VDR and $\beta$-catenin signaling. Therefore, function of $\beta$-catenin rather than expression appears to be altered by VDR in hair follicles, possibly with different impact depending on the stage of hair follicle cycling.

\section{VDR as a tumor suppressor in skin}

Over 1 million skin cancers occur annually in the United States, $80 \%$ of which are basal cell carcinomas (BCC) ((16\% squamous cell carcinomas (SCC), $4 \%$ melanomas)), making it by far the most common cancer[108]. Ultraviolet radiation (UVR) is the major etiologic agent. UV wavelengths shorter than $280 \mathrm{~nm}$ (UVC) are absorbed by the ozone layer and do not reach the earth. UV wavelengths longer than $320 \mathrm{~nm}$ (UVA) have limited ability to induce the characteristic mutations in DNA seen in epidermal cancers. Thus UVB with a spectrum between 280 and $320 \mathrm{~nm}$ is the major cause of these cancers [109]. The principle genotoxic lesions induced by UVR are cyclobutane pyrimidine dimers (CPDs) and pyrimidine[4]pyrimidone photoproducts (6-4PP), which if not repaired result in $\mathrm{C}$ to $\mathrm{T}$ or CC to TT mutations, the UVB "signature" lesion[110]. Such mutations in p53 are common (50-90\%) in both BCC and SCC [111-114] as well as in actinic keratoses, the precursor lesions to SCC[114]. Mutations in ras are much more common in SCC than BCC [115], whereas mutations in the hedgehog $(\mathrm{Hh})$ signaling pathway, in particular in patched 1 (Ptch 1), characterize BCC[116-120], but can also be found in SCC in patients also susceptible to $\mathrm{BCC}$ [121]. SCC arise from epidermal precursor lesions, whereas BCC appear to arise from hair follicle and epidermal stem cells [122].

Vitamin D plays a protective role in the skin with respect to carcinogenesis. Zinser et al. [123] treated VDR null mice bearing medroxyprogesterone pellets with two oral administrations of 7,12 dimethylbenzanthracene (DMBA) at 5.5 and 7 weeks, a protocol designed to induce breast cancers. No breast tumors were observed at least initially. Instead they found that $85 \%$ of the VDR null mice developed skin tumors within 2 months. No tumors (breast or skin) were found in the wildtype controls. The tumors were mostly sebaceous, squamous, and follicular papillomas, but several BCC were observed. No SCC were reported. These results have been confirmed using topical administration of DMBA/ TPA, although only papillomas were seen in the VDR null mice unlike RXRa null mice that developed both BCC and SCC[124]. A study by Ellison et al. [125] confirmed the results by Zinser et al. [123], and further demonstrated that mice lacking CYP27B1 (and so lacking $1,25(\mathrm{OH})_{2} \mathrm{D}$ ) were not prone to DMBA induced tumors. This group [125] then demonstrated that the VDR null mice were more susceptible to tumor formation induced by UVR. We 
[82] have confirmed these results with UVR, and showed that CYP27B1 null mice were not more susceptible to UVR induced tumor formation than wildtype controls similar to the observations with DMBA. Thus susceptibility to epidermal tumor formation is found in VDR null but not CYP27B1 null mice, analogous to the discrepancy between VDR null and CYP27B1 null mice with respect to disruption of hair follicle signaling. Given the origin of $\mathrm{BCC}$ from hair follicle stem cells, this correlation is likely to be more than fortuitous. Furthermore, UVR induced tumors include BCC as well as SCC [82]. The appearance of $\mathrm{BCC}$ in these studies is atypical since the typical malignancy induced in mouse skin by UVR, ionizing radiation, or chemical carcinogens is SCC not BCC[111] again supporting a primary defect in hair follicle stem cells as a predisposing factor for tumorigenesis in these mice.

Although the CYP27B1 null mice do not appear to be predisposed to tumor formation under the conditions studied, the protective role of $1,25(\mathrm{OH})_{2} \mathrm{D}$ against tumor formation cannot be totally discounted. As noted earlier, CPD formation is indicative of UVB induced DNA damage. The Mason laboratory demonstrated in cultured keratinocytes and in vivo that $1,25(\mathrm{OH})_{2} \mathrm{D}$ and several non genomic analogs reduced and/or facilitated the repair of UVB induced CPD formation and protected the cells from apoptosis [126, 127]. This protection was associated with an increase in p53 [127, 128]. The protective action of non genomic analogs of $1,25(\mathrm{OH})_{2} \mathrm{D}$ suggests that the mechanisms involved do not require the increased synthesis of proteins including p53, but this has not been rigorously tested. Our own studies $[31,82]$ in VDR null mice demonstrate a decreased clearance in both CPDs and hyperplasia following acute UVB exposure, but no differences from controls were seen in the CYP27B1 null mice (Teichert and Bikle, unpublished observations). However, as will be discussed below, $1,25(\mathrm{OH})_{2} \mathrm{D}$ does regulate both the hedgehog $(\mathrm{Hh})$ and $\beta$-catenin pathways that when activated may predispose to tumor formation in the VDR null mice.

\section{The hedgehog $(\mathrm{Hh})$ pathway in epidermal tumor formation}

The Hh pathway is depicted in Fig. 5. The appearance of BCC is characteristic of tumors formed when Hh signaling is disrupted [118], although activation of $\mathrm{Hh}$ signaling $\left(\mathrm{Ptch}^{-/+}\right.$ mice) also predisposes to UVR induced SCC formation [121], and a polymorphism of Ptch has been observed to promote Hras induced SCC formation [131]. We [82] have found that the epidermis and epidermal portion (utricles) of the hair follicles of adult VDR null animals overexpress elements of the Hh signaling pathway unlike the dermal portion of the hair follicle in which Hh signaling is reduced [40]. These results suggest that one of the causes of the increased susceptibility of the epidermis to malignant transformation is due to a loss of VDR regulation of Hh signaling in the epidermis. Furthermore, we [82] found that $1,25(\mathrm{OH})_{2} \mathrm{D}$ suppressed all elements of the Hh pathway in a dose dependent fashion that required the VDR (no repression in VDR null epidermis). Indeed, the promoters of Shh and Gli1 have been found to bind VDR [107]. Of further interest is that vitamin D may regulate this pathway not only via the genomic actions of $1,25(\mathrm{OH})_{2} \mathrm{D}$ acting through its receptor, VDR, but also by direct inhibition by vitamin $\mathrm{D}$ independent of its receptor. The latter possibility stems from recent observations that vitamin D itself as well as its precursor 7dehydrocholesterol can bind to and inhibit the actions of smoothened (Smoh), a critical step in Hh signaling[132, 133]. 1,25(OH) $)_{2} \mathrm{D}$ was less effective [133] suggesting a direct effect of vitamin D itself.

Appreciation of the pivotal role of the Hh signaling pathway in BCC development began with the identification of the Ptch1 gene as the site of mutations underlying the rare autosomal dominant heritable basal cell nevus syndrome (BCNS) (Gorlin Syndrome), one of whose cardinal features is a high susceptibility to the development of BCCs [118, 119]. The BCCs in these subjects frequently lose function of the inherited wildtype Ptch 1 allele, leaving the tumor cells functionally null of Ptch1. Subsequently it has become clear that 
essentially all BCCs, whether arising in patients with BCNS or sporadically, have mutations in Ptch 1 or other alterations in Hh signaling [119]. This appreciation has resulted in the development of the Ptch1+/- (Gorlin) mouse as the first practical model of murine BCCs [120]. Treatment of these mice (unlike treatment of Ptch 1 wildtype mice) with UVR or ionizing radiation produces BCC as well as SCC [120].

Ptch 1 is the membrane receptor for Shh. In the absence of Shh, Ptch 1 inhibits the function of another membrane protein smoothened (Smoh). Shh reverses this inhibition freeing Smoh to enable the activation of a family of transcription factors Gli1, Gli2, and Gli3. Suppressor of fused (Sufu) may maintain these transcription factors in the cytoplasm and/or limit their activity in the nucleus such that the loss of Sufu leads to increased Hh signaling [130, 134]. However, mutations in Sufu have not been clearly shown to result in BCC, although they are associated with medulloblastomas, a feature of the Gorlin syndrome [116]. The role of Gli3 is unclear, and unlike Gli1 and Gli2, it is not elevated in BCC. Gli1 and 2 overexpression in keratinocytes can increase the expression of each other as well as Ptch 1, the anti apoptotic factor bc12, cyclins D1 and D2, E2F1, cdc45 (all of which promote proliferation) while suppressing genes associated with keratinocyte differentiation such as K1, K10, involucrin, loricrin and the VDR [129, 135-138]. 1,25(OH) 2 D and VDR, on the other hand, have the opposite action on these genes. Mice overexpressing Gli1, Gli2, or Shh in their basal keratinocytes [137-139] or grafted with human keratinocytes overexpressing Shh [140] develop BCC like lesions. Furthermore, BCC show overexpression of Ptch1, Smoh, Gli1 and Gli2 [141, 142]. Gli2 null mice resemble Shh null animals in phenotype, Gli2 deletion partially rescues Ptch 1 null animals, and Gli2 is required for Shh signaling in hair follicle development [143]. Shh, Ptch1, Ptch2, Gli1 and Gli2 have consensus sequences for vitamin D response elements (VDRE) in their promoters $[84,107,144]$ suggesting that $1,25(\mathrm{OH})_{2} \mathrm{D} /$ VDR may regulate their expression directly as indicated by our results with $1,25(\mathrm{OH})_{2} \mathrm{D}$ inhibition of their expression [82].

\section{$\beta$-catenin signaling in epidermal tumor formation}

The appearance of hair follicle elements in many of the tumors forming in the VDR null mouse skin also suggests that the $\beta$-catenin pathway is disrupted. Like the Hh pathway, over expression and/or activating mutations in the $\beta$-catenin pathway lead to skin tumors, in this case pilomatricomas or trichofolliculomas (hair follicle tumors) as previously mentioned [77-79]. Palmer et al. [84] evaluated the interaction between VDR and $\beta$-catenin in transcriptional regulation, and identified putative response elements for VDR and $\beta$-catenin/ LEF in a number of genes including Shh, Ptch1 and 2, Gli1 and 2. Furthermore, they found that the ability of $\beta$-catenin overexpression to induce trichofolliculomas was blocked by an analog of $1,25(\mathrm{OH})_{2} \mathrm{D}$, and in the absence of VDR, BCC were induced rather than trichofolliculomas.

In human tumors Palmer et al. [84] noted that trichofolliculomas have high nuclear levels of both $\beta$-catenin and VDR, whereas BCC have high levels of $\beta$-catenin but low levels of VDR. These observations are consistent with their animal data showing that lack of VDR in the skin of animals with activated $\beta$-catenin results in BCC. Saldanha et al. [145] likewise found nuclear localization of $\beta$-catenin in 20 of $86 \mathrm{BCC}$, which correlated with increased proliferative activity in these tumors, but they did not correlate these results with VDR levels. Thus in humans as well as mice, VDR appears to modulate the differential action of $\beta$-catenin signal in the hair follicle and in the epidermis.

The $\beta$-catenin and Shh pathways interact $[76,84]$. Both are required for normal hair follicle development and cycling. Putative $\beta$-catenin/LEF response elements have been found in a number of Hh pathway genes [84]. Conditional deletion of $\beta$-catenin eliminates Shh expression from the hair follicle [103] and tongue [146], whereas Shh inhibits $\beta$-catenin 
transcriptional activity [146]. The degree to which $\beta$-catenin/Shh interactions occur in the formation of skin cancer much less the role vitamin D plays in these interactions has not been rigorously examined.

\section{Ligand dependent vs independent actions of VDR in preventing skin cancer}

Our working model by which $1,25(\mathrm{OH})_{2} \mathrm{D}$ and its receptor VDR regulate the $\mathrm{Hh}$ and $\beta$ catenin signaling pathways is shown in Fig. 6. As discussed above, most skin tumors induced by systemic DMBA in mice lacking the VDR contain hair follicle elements and/or are of basal cell origin, tumors characteristic of overexpression of the $\mathrm{Hh}$ and $\beta$-catenin pathways in keratinocytes. UVR induces mostly SCC but some BCC in VDR null animals $[82,125]$. The VDR is found in the outer root sheath, bulge stem cells and basal layer of the interfollicular epidermis, a postulated source for BCC development [39, 122], but the VDR is also found in the upper layers of the epidermis where it promotes differentiation. Lack of VDR causes a hyperproliferative response in the keratinocytes of the outer root sheath of the hair follicle and basal layer of epidermis during catagen (days 15-19), with disruption of normal hair follicle cycling and altered epidermal differentiation $[38,39]$. We postulate that increased $\mathrm{Hh}$ and $\beta$-catenin signaling in the keratinocytes of the VDR null animal predisposes the skin to the development of tumors in part by stimulating proliferation and reducing differentiation. At this point it is unclear the degree to which the role of VDR is ligand (i.e. $1,25(\mathrm{OH})_{2} \mathrm{D}$ ) dependent or independent. Disruption of hair follicle cycling in the VDR null mouse is accompanied by both hyperproliferation and increased apoptosis in the hair follicle [39]; disruption of hair follicle cycling is not found in the CYP27B1 null mouse [39]. Furthermore, we were unable to show that mice lacking $1,25(\mathrm{OH})_{2} \mathrm{D}_{3}$ production (CYP27B1 null) had increased susceptibility to UVR induced tumor formation. Thus, $1,25(\mathrm{OH})_{2} \mathrm{D}$ may have only a synergistic role regarding UVR induced tumor formation in the epidermis, but its ability to suppress both $\mathrm{Hh}$ and $\beta$-catenin signaling indicates this synergistic role is important.

\section{Conclusions}

Vitamin D and its receptor have many roles in the skin. Some of these roles-induction of genes required for differentiation, suppression of genes involved with proliferation-appear to require both $1,25(\mathrm{OH})_{2} \mathrm{D}$ and VDR. Other roles such as regulation of hair follicle cycling and tumor suppression do not appear to require $1,25(\mathrm{OH})_{2} \mathrm{D}$, although other ligands may compensate. Different coactivator complexes including DRIP and SRC modulate the actions of VDR, and the choice of coactivator complex in many cases is gene specific. Regulation of proliferation is dependent on DRIP, whereas more differentiated functions including innate immunity and permeability barrier formation are SRC dependent. $\mathrm{Hr}$ is a coregulator with profound actions in hair follicle cycling. Although Hr blocks $1,25(\mathrm{OH})_{2} \mathrm{D}$ regulated VDR functions in epidermal keratinocytes, its role in VDR regulated hair follicle cycling is less clear. $\beta$-catenin interactions with VDR can enhance VDR induction of some genes, whereas VDR can suppress $\beta$-catenin induction of other genes. Many genes in the skin contain both putative VDREs and LEF/TCF sites. Like $\beta$-catenin, the Hh pathway is critical for hair follicle cycling, and again like $\beta$-catenin, the Hh pathway is differentially regulated in the interfollicular epidermis compared to the proximal hair follicle. Both $\beta$-catenin and $\mathrm{Hh}$ pathways are likely mediators of the predisposition of VDR null animals to epidermal tumor formation, although other mechanisms including DNA repair are likely to contribute. At this point we are a long ways away from understanding how vitamin $\mathrm{D}$ via its active metabolite(s) and receptor (VDR) regulate all the various functions in the skin that it appears to regulate. But what we have learned indicates that the skin is a fertile area for understanding the mechanisms by which vitamin D regulates so many different physiologic processes. 


\section{Key unanswered questions}

1. How essential is local production of $1,25(\mathrm{OH}) 2 \mathrm{D}$ in the keratinocytes of the epidermis and hair follicles for the normal regulation of proliferation and differentiation including that barrier formation and innate immunity?

2. How specific are the roles of the coactivators regulating different vitamin $\mathrm{D}$ target genes, and do these require $1,25(\mathrm{OH}) 2 \mathrm{D}$ in all cases?

3. Is there a ligand for VDR in the skin other than $1,25(\mathrm{OH}) 2 \mathrm{D}$ that can mediate the actions of the VDR in hair follicle cycling and protection against tumor development?

4. How do VDR and hairless interact to regulate hair follicle cycling?

5. What are the critical pathways by which $1,25(\mathrm{OH}) 2 \mathrm{D}$ and VDR regulate UV induced tumorigenesis?

6. Is there a level of exposure to UVR that optimizes vitamin D production in skin without increasing the risk of aging and malignancy?

\section{Acknowledgments}

The author acknowledges the administrative assistance of Teresa Tong. The work discussed is primarily that done by a talented group researchers including Drs. Arnaud Teichert, Yuko Oda, Chia-Ling Tu, and Zhongjian Xie supported by the technical assistance of Hashem Elalieh and Vadim Bul. The work was supported by grants from the NIH RO1s AR050023, AR051930, PO1 AR39448, AICR 07A140, and a VA Merit Review.

\section{References}

1. Bikle DD, Pillai S. Vitamin D, calcium, and epidermal differentiation. Endocr Rev. 1993; 14:3-19. [PubMed: 8491153]

2. Tu CL, Chang W, Bikle DD. The extracellular calcium-sensing receptor is required for calciuminduced differentiation in human keratinocytes. J Biol Chem. 2001; 276:41079-41085. [PubMed: 11500521]

3. Tu CL, Chang W, Bikle DD. Phospholipase cgamma1 is required for activation of store-operated channels in human keratinocytes. J Invest Dermatol. 2005; 124:187-197. [PubMed: 15654973]

4. Tu C, Chang W, Xie Z, Bikle D. Inactivation of the calcium sensing receptor inhibits E-cadherinmediated cell-cell adhesion and calcium-induced differentiation in human epidermal keratinocytes. J Biol Chem. 2008; 283:3519-3528. [PubMed: 18065418]

5. Xie Z, Singleton PA, Bourguignon LY, Bikle DD. Calcium-induced human keratinocyte differentiation requires src- and fyn-mediated phosphatidylinositol 3-kinase-dependent activation of phospholipase C-gamma1. Mol Biol Cell. 2005; 16:3236-3246. [PubMed: 15872086]

6. Xie Z, Bikle DD. The recruitment of phosphatidylinositol 3-kinase to the E-cadherin-catenin complex at the plasma membrane is required for calcium-induced phospholipase C-gamma1 activation and human keratinocyte differentiation. J Biol Chem. 2007; 282:8695-8703. [PubMed: 17242406]

7. Xie Z, Chang SM, Pennypacker SD, Liao EY, Bikle DD. Phosphatidylinositol-4-phosphate 5-kinase 1alpha mediates extracellular calcium-induced keratinocyte differentiation. Mol Biol Cell. 2009; 20:1695-1704. [PubMed: 19158393]

8. Yuspa SH, Kilkenny AE, Steinert PM, Roop DR. Expression of murine epidermal differentiation markers is tightly regulated by restricted extracellular calcium concentrations in vitro. J Cell Biol. 1989; 109:1207-1217. [PubMed: 2475508]

9. Hohl D. Cornified cell envelope. Dermatologica. 1990; 180:201-211. [PubMed: 2192924]

10. Thacher SM, Rice RH. Keratinocyte-specific transglutaminase of cultured human epidermal cells: relation to cross-linked envelope formation and terminal differentiation. Cell. 1985; 40:685-695. [PubMed: 2578891] 
11. Hennings H, Steinert P, Buxman MM. Calcium induction of transglutaminase and the formation of epsilon(gamma-glutamyl) lysine cross-links in cultured mouse epidermal cells. Biochem Biophys Res Commun. 1981; 102:739-745. [PubMed: 6118152]

12. Menon GK, Grayson S, Elias PM. Ionic calcium reservoirs in mammalian epidermis: ultrastructural localization by ion-capture cytochemistry. J Invest Dermatol. 1985; 84:508-512. [PubMed: 3998499]

13. Tu CL, Oda Y, Komuves L, Bikle DD. The role of the calcium-sensing receptor in epidermal differentiation. Cell Calcium. 2004; 35:265-273. [PubMed: 15200150]

14. Brown EM, Gamba G, Riccardi D, Lombardi M, Butters R, Kifor O, et al. Cloning and characterization of an extracellular $\mathrm{Ca}-2+-$ sensing receptor from bovine parathyroid. Nature. 1993; 366:575-580. [PubMed: 8255296]

15. Oda Y, Tu CL, Pillai S, Bikle DD. The calcium sensing receptor and its alternatively spliced form in keratinocyte differentiation. J Biol Chem. 1998; 273:23344-23352. [PubMed: 9722568]

16. Chang W, Tu C, Chen TH, Bikle D, Shoback D. The extracellular calcium-sensing receptor (CaSR) is a critical modulator of skeletal development. Sci Signal. 2008; 1:1-13. [PubMed: 18364512]

17. Ratnam AV, Bikle DD, Cho JK. 1,25 dihydroxyvitamin D3 enhances the calcium response of keratinocytes. J Cell Physiol. 1999; 178:188-196. [PubMed: 10048583]

18. Xie Z, Bikle DD. Cloning of the human phospholipase C-gamma1 promoter and identification of a DR6-type vitamin D-responsive element. J Biol Chem. 1997; 272:6573-6577. [PubMed: 9045685]

19. Xie Z, Bikle DD. Phospholipase C-gamma1 is required for calcium-induced keratinocyte differentiation. J Biol Chem. 1999; 274:20421-20424. [PubMed: 10400667]

20. Xie Z, Bikle DD. Inhibition of 1,25-Dihydroxyvitamin-D-Induced keratinocyte differentiation by blocking the expression of phospholipase C-gamma1. J Invest Dermatol. 2001; 117:1250-1254. [PubMed: 11710940]

21. Su MJ, Bikle DD, Mancianti ML, Pillai S. 1,25-Dihydroxyvita-min D3 potentiates the keratinocyte response to calcium. J Biol Chem. 1994; 269:14723-14729. [PubMed: 7910167]

22. Ng DC, Shafaee S, Lee D, Bikle DD. Requirement of an AP-1 site in the calcium response region of the involucrin promoter. J Biol Chem. 2000; 275:24080-24088. [PubMed: 10816578]

23. Bikle DD, Ng D, Oda Y, Hanley K, Feingold K, Xie Z. The vitamin D response element of the involucrin gene mediates its regulation by 1,25-dihydroxyvitamin D3. J Invest Dermatol. 2002; 119:1109-1113. [PubMed: 12445200]

24. Pillai S, Bikle DD. Role of intracellular-free calcium in the cornified envelope formation of keratinocytes: differences in the mode of action of extracellular calcium and 1,25 dihydroxyvitamin D3. J Cell Physiol. 1991; 146:94-100. [PubMed: 1990023]

25. Bikle DD, Pillai S, Gee E. Squamous carcinoma cell lines produce 1,25 dihydroxyvitamin D, but fail to respond to its prodifferentiating effect. J Invest Dermatol. 1991; 97:435-41. [PubMed: 1875043]

26. Hosomi J, Hosoi J, Abe E, Suda T, Kuroki T. Regulation of terminal differentiation of cultured mouse epidermal cells by 1 alpha,25-dihydroxyvitamin D3. Endocrinology. 1983; 113:1950-1957. [PubMed: 6196178]

27. Smith EL, Walworth NC, Holick MF. Effect of 1 alpha,25-dihydroxyvitamin D3 on the morphologic and biochemical differentiation of cultured human epidermal keratinocytes grown in serum-free conditions. J Invest Dermatol. 1986; 86:709-714. [PubMed: 2423618]

28. McLane JA, Katz M, Abdelkader N. Effect of 1,25-dihydroxyvitamin D3 on human keratinocytes grown under different culture conditions. In Vitro Cell Dev Biol. 1990; 26:379-387. [PubMed: 2345124]

29. Hawker NP, Pennypacker SD, Chang SM, Bikle DD. Regulation of human epidermal keratinocyte differentiation by the vitamin D receptor and its coactivators DRIP205, SRC2, and SRC3. J Invest Dermatol. 2007; 127:874. [PubMed: 17082781]

30. Matsumoto K, Hashimoto K, Nishida Y, Hashiro M, Yoshikawa K. Growth-inhibitory effects of 1,25-dihydroxyvitamin D3 on normal human keratinocytes cultured in serum-free medium. Biochem Biophys Res Commun. 1990; 166:916-923. [PubMed: 2405860] 
31. Bikle DD. The vitamin D receptor: a tumor suppressor in skin. Discov Med. 2011; 11:7-17. [PubMed: 21276406]

32. Oda Y, Uchida Y, Moradian S, Crumrine D, Elias P, Bikle D. Vitamin D receptor and coactivators SRC 2 and 3 regulate epidermis-specific sphingolipid production and permeability barrier formation. J Invest Dermatol. 2009; 129:1367-1378. [PubMed: 19052561]

33. Schauber J, Dorschner RA, Coda AB, Buchau AS, Liu PT, Kiken D, et al. Injury enhances TLR2 function and antimicrobial peptide expression through a vitamin D-dependent mechanism. J Clin Invest. 2007; 117:803-811. [PubMed: 17290304]

34. Schauber J, Dorschner RA, Yamasaki K, Brouha B, Gallo RL. Control of the innate epithelial antimicrobial response is cell-type specific and dependent on relevant microenvironmental stimuli. Immunology. 2006; 118:509-519. [PubMed: 16895558]

35. Li YC, Pirro AE, Amling M, Delling G, Baron R, Bronson R, et al. Targeted ablation of the vitamin D receptor: an animal model of vitamin D-dependent rickets type II with alopecia. Proc Natl Acad Sci USA. 1997; 94:9831-9835. [PubMed: 9275211]

36. Yoshizawa T, Handa Y, Uematsu Y, Takeda S, Sekine K, Yoshihara Y, et al. Mice lacking the vitamin $\mathrm{D}$ receptor exhibit impaired bone formation, uterine hypoplasia and growth retardation after weaning. Nat Genet. 1997; 16:391-396. [PubMed: 9241280]

37. Malloy PJ, Pike JW, Feldman D. The vitamin D receptor and the syndrome of hereditary 1,25dihydroxyvitamin D-resistant rickets. Endocr Rev. 1999; 20:156-188. [PubMed: 10204116]

38. Xie Z, Komuves L, Yu QC, Elalieh H, Ng DC, Leary C, et al. Lack of the vitamin D receptor is associated with reduced epidermal differentiation and hair follicle growth. J Invest Dermatol. 2002; 118:11-16. [PubMed: 11851870]

39. Bikle DD, Elalieh H, Chang S, Xie Z, Sundberg JP. Development and progression of alopecia in the vitamin D receptor null mouse. J Cell Physiol. 2006; 207:340-353. [PubMed: 16419036]

40. Teichert A, Elalieh H, Bikle D. Disruption of the hedgehog signaling pathway contributes to the hair follicle cycling deficiency in Vdr knockout mice. J Cell Physiol. 2010; 225:482-489. [PubMed: 20458748]

41. Bikle DD, Chang S, Crumrine D, Elalieh H, Man MQ, Choi EH, et al. 25 Hydroxyvitamin D 1 alpha-hydroxylase is required for optimal epidermal differentiation and permeability barrier homeostasis. J Invest Dermatol. 2004; 122:984-992. [PubMed: 15102089]

42. Muehleisen B, Bikle D, Gallo RL. Interplay of vitamin D and innate immune responses affects bacterial skin infection. J Invest Dermatol. 2011; 131:S1-S141. Abstracts \#631.

43. Makishima M, Lu TT, Xie W, Whitfield GK, Domoto H, Evans RM, et al. Vitamin D receptor as an intestinal bile acid sensor. Science. 2002; 296:1313-1316. [PubMed: 12016314]

44. Peric M, Koglin S, Dombrowski Y, Gross K, Bradac E, Ruzicka T, et al. VDR and MEK-ERK dependent induction of the antimicrobial peptide cathelicidin in keratinocytes by lithocholic acid. Mol Immunol. 2009; 46:3183-3187. [PubMed: 19733911]

45. Zbytek B, Janjetovic Z, Tuckey RC, Zmijewski MA, Sweatman TW, Jones E, et al. 20Hydroxyvitamin D3, a product of vitamin D3 hydroxylation by cytochrome P450scc, stimulates keratinocyte differentiation. J Invest Dermatol. 2008; 128:2271-2280. [PubMed: 18368131]

46. Zehnder D, Bland R, Williams MC, McNinch RW, Howie AJ, Stewart PM, et al. Extrarenal expression of 25-hydroxyvitamin d(3)-1 alpha-hydroxylase. J Clin Endocrinol Metab. 2001; 86:888-894. [PubMed: 11158062]

47. Milde P, Hauser U, Simon T, Mall G, Ernst V, Haussler MR, et al. Expression of 1,25dihydroxyvitamin D3 receptors in normal and psoriatic skin. J Invest Dermatol. 1991; 97:230-239. [PubMed: 1649228]

48. Stumpf WE, Clark SA, Sar M, DeLuca HF. Topographical and developmental studies on target sites of 1,25 (OH)2 vitamin D3 in skin. Cell Tissue Res. 1984; 238:489-496. [PubMed: 6098372]

49. Oda Y, Sihlbom C, Chalkley RJ, Huang L, Rachez C, Chang CP, et al. Two distinct coactivators, $\mathrm{DRIP} /$ mediator and SRC/ $\mathrm{p} 160$, are differentially involved in vitamin D receptor transactivation during keratinocyte differentiation. Mol Endocrinol. 2003; 17:2329-2339. [PubMed: 12893881]

50. McKenna NJ, Lanz RB, O’Malley BW. Nuclear receptor coregulators: cellular and molecular biology. Endocr Rev. 1999; 20:321-344. [PubMed: 10368774] 
51. Oda Y, Ishikawa MH, Hawker NP, Yun QC, Bikle DD. Differential role of two VDR coactivators, DRIP205 and SRC-3, in keratinocyte proliferation and differentiation. J Steroid Biochem Mol Biol. 2007; 103:776-780. [PubMed: 17223341]

52. Schauber J, Oda Y, Buchau AS, Steinmeyer A, Zugel U, Bikle DD, et al. Histone acetylation in keratinocytes enables control of the expression of cathelicidin and CD14 by 1,25dihydroxyvitamin D3. J Invest Dermatol. 2008; 128:816-824. [PubMed: 17943182]

53. Rachez C, Lemon BD, Suldan Z, Bromleigh V, Gamble M, Naar AM, et al. Ligand-dependent transcription activation by nuclear receptors requires the DRIP complex. Nature. 1999; 398:824828. [PubMed: 10235266]

54. Rachez C, Gamble M, Chang CP, Atkins GB, Lazar MA, Freedman LP. The DRIP complex and SRC-1/p160 coactivators share similar nuclear receptor binding determinants but constitute functionally distinct complexes. Mol Cell Biol. 2000; 20:2718-2726. [PubMed: 10733574]

55. Leo C, Chen JD. The SRC family of nuclear receptor coactivators. Genes. 2000; 245:1-11.

56. Teichert A, Arnold LA, Otieno S, Oda Y, Augustinaite I, Geistlinger TR, et al. Quantification of the vitamin D receptorcoregulator interaction. Biochemistry. 2009; 48:1454-1461. [PubMed: 19183053]

57. Acevedo ML, Lee KC, Stender JD, Katzenellenbogen BS, Kraus WL. Selective recognition of distinct classes of coactivators by a ligand-inducible activation domain. Mol Cell. 2004; 13:725738. [PubMed: 15023342]

58. Christakos S, Dhawan P, Liu Y, Peng X, Porta A. New insights into the mechanisms of vitamin D action. J Cell Biochem. 2003; 88:695-705. [PubMed: 12577303]

59. Rachez C, Freedman LP. Mechanisms of gene regulation by vitamin D(3) receptor: a network of coactivator interactions. Gene. 2000; 246:9-21. [PubMed: 10767523]

60. Carvallo L, Henriquez B, Paredes R, Olate J, Onate S, Van Wijnen AJ, et al. 1,25-dihydroxy vitamin D3-enhanced expression of the osteocalcin gene involves increased promoter occupancy of basal transcription regulators and gradual recruitment of the 1,25-dihydroxy vitamin D3 receptor-SRC-1 coactivator complex. J Cell Physiol. 2008; 214:740-749. [PubMed: 17786964]

61. Issa LL, Leong GM, Sutherland RL, Eisman JA. Vitamin D analogue-specific recruitment of vitamin D receptor coactivators. J Bone Miner Res. 2002; 17:879-890. [PubMed: 12009019]

62. Bouillon R, Verlinden L, Eelen G, De Clercq P, Vandewalle M, Mathieu C, et al. Mechanisms for the selective action of vitamin D analogs. J Steroid Biochem Mol Biol. 2005; 97:21-30. [PubMed: 16111885]

63. Maeda Y, Rachez C, Hawel IL, Byus CV, Freedman LP, Sladek FM. Polyamines modulate the interaction between nuclear receptors and vitamin D receptor-interacting protein 205. Mol Endocrinol. 2002; 16:1502-1510. [PubMed: 12089346]

64. Peleg S, Ismail A, Uskokovic M, Avnur Z. Evidence for tissueand cell-type selective activation of the vitamin D receptor by Ro-26-9228, a noncalcemic analog of vitamin D3. J Cell Biochem. 2003; 88:267-273. [PubMed: 12520525]

65. Schauber J, Oda Y, Buchau AS, Yun QC, Steinmeyer A, Zugel U, et al. Histone acetylation in keratinocytes enables control of the expression of cathelicidin and CD14 by 1,25Dihydroxyvitamin D(3). J Invest Dermatol. 2008; 128:816-824. [PubMed: 17943182]

66. Bikle DD, Teichert A, Arnold LA, Uchida Y, Elias PM, Oda Y. Differential regulation of epidermal function by VDR coactiva-tors. J Steroid Biochem Mol Biol. 2010; 121:308-313. [PubMed: 20298785]

67. Beaudoin GM III, Sisk JM, Coulombe PA, Thompson CC. Hairless triggers reactivation of hair growth by promoting Wnt signaling. Proc Natl Acad Sci USA. 2005; 102:14653-14658. [PubMed: 16195376]

68. Djabali K, Aita VM, Christiano AM. Hairless is translocated to the nucleus via a novel bipartite nuclear localization signal and is associated with the nuclear matrix. J Cell Sci. 2001; 114:367376. [PubMed: 11148138]

69. Liu L, Kim H, Casta A, Luke C, Kobayashi Y, Shapiro LS, et al. Hairless is a H3K9 histone demethylase. J Invest Dermatol. 2011; 131:S1-S141. S169 \#409.

70. Thompson CC, Bottcher MC. The product of a thyroid hormoneresponsive gene interacts with thyroid hormone receptors. Proc Natl Acad Sci USA. 1997; 94:8527-8532. [PubMed: 9238010] 
71. Engelhard A, Christiano AM. The hairless promoter is differentially regulated by thyroid hormone in keratinocytes and neuroblastoma cells. Exp Dermatol. 2004; 13:257-264. [PubMed: 15086342]

72. Xie Z, Chang S, Oda Y, Bikle DD. Hairless suppresses vitamin D receptor transactivation in human keratinocytes. Endocrinology. 2006; 147:314-323. [PubMed: 16269453]

73. Hsieh JC, Sisk JM, Jurutka PW, Haussler CA, Slater SA, Haussler MR, et al. Physical and functional interaction between the vitamin $\mathrm{D}$ receptor and hairless corepressor, two proteins required for hair cycling. J Biol Chem. 2003; 278:38665-38674. [PubMed: 12847098]

74. Zarach JM, Beaudoin 3rd GM, Coulombe PA, Thompson CC. The co-repressor hairless has a role in epithelial cell differentiation in the skin. Development. 2004; 131:4189-4200. [PubMed: 15280217]

75. He TC, Sparks AB, Rago C, Hermeking H, Zawel L, da Costa LT, et al. Identification of c-MYC as a target of the APC pathway. Science. 1998; 281:1509-1512. [PubMed: 9727977]

76. Bienz M. beta-Catenin: a pivot between cell adhesion and Wnt signalling. Curr Biol. 2005; 15:R64-R67. [PubMed: 15668160]

77. Chan EF, Gat U, McNiff JM, Fuchs E. A common human skin tumour is caused by activating mutations in beta-catenin. Nat Genet. 1999; 21:410-413. [PubMed: 10192393]

78. Gat U, DasGupta R, Degenstein L, Fuchs E. De Novo hair follicle morphogenesis and hair tumors in mice expressing a truncated beta-catenin in skin. Cell. 1998; 95:605-614. [PubMed: 9845363]

79. Xia J, Urabe K, Moroi Y, Koga T, Duan H, Li Y, et al. beta-Catenin mutation and its nuclear localization are confirmed to be frequent causes of Wnt signaling pathway activation in pilomatricomas. J Dermatol Sci. 2006; 41:67-75. [PubMed: 16378715]

80. Palmer HG, Gonzalez-Sancho JM, Espada J, Berciano MT, Puig I, Baulida J, et al. Vitamin D(3) promotes the differentiation of colon carcinoma cells by the induction of E-cadherin and the inhibition of beta-catenin signaling. J Cell Biol. 2001; 154:369-387. [PubMed: 11470825]

81. Shah S, Hecht A, Pestell R, Byers SW. Trans-repression of betacatenin activity by nuclear receptors. J Biol Chem. 2003; 278:48137-48145. [PubMed: 12972427]

82. Teichert A, Elalieh H, Elias P, Welsh J, Bikle D. Over-expression of hedgehog signaling is associated with epidermal tumor formation in vitamin D receptor null mice. J Invest Dermatol. 2011 (in press).

83. Shah S, Islam MN, Dakshanamurthy S, Rizvi I, Rao M, Herrell R, et al. The molecular basis of vitamin D receptor and beta-catenin crossregulation. Mol Cell. 2006; 21:799-809. [PubMed: 16543149]

84. Palmer HG, Anjos-Afonso F, Carmeliet G, Takeda H, Watt FM. The vitamin D receptor is a Wnt Effector that controls hair follicle differentiation and specifies tumor type in adult epidermis. PLoS ONE. 2008; 3:e1483. [PubMed: 18213391]

85. Cianferotti L, Cox M, Skorija K, Demay MB. Vitamin D receptor is essential for normal keratinocyte stem cell function. Proc Natl Acad Sci USA. 2007; 104:9428-9433. [PubMed: 17517646]

86. Shimizu H, Morgan BA. Wnt signaling through the beta-catenin pathway is sufficient to maintain, but not restore, anagen-phase characteristics of dermal papilla cells. J Invest Dermatol. 2004; 122:239-245. [PubMed: 15009701]

87. Kishimoto J, Burgeson RE, Morgan BA. Wnt signaling maintains the hair-inducing activity of the dermal papilla. Genes Dev. 2000; 14:1181-1185. [PubMed: 10817753]

88. Morris RJ, Liu Y, Marles L, Yang Z, Trempus C, Li S, et al. Capturing and profiling adult hair follicle stem cells. Nat Biotechnol. 2004; 22:411-417. [PubMed: 15024388]

89. Langbein L, Rogers MA, Praetzel S, Winter H, Schweizer J. K6irs1, K6irs2, K6irs3, and K6irs4 represent the inner-rootsheath-specific type II epithelial keratins of the human hair follicle. J Invest Dermatol. 2003; 120:512-522. [PubMed: 12648212]

90. Zhou P, Byrne C, Jacobs J, Fuchs E. Lymphoid enhancer factor 1 directs hair follicle patterning and epithelial cell fate. Genes Dev. 1995; 9:700-713. [PubMed: 7537238]

91. Hochberg Z, Gilhar A, Haim S, Friedman-Birnbaum R, Levy J, Benderly A. Calcitriol-resistant rickets with alopecia. Arch Dermatol. 1985; 121:646-647. [PubMed: 2986561]

92. Marx SJ, Bliziotes MM, Nanes M. Analysis of the relation between alopecia and resistance to 1,25-dihydroxyvitamin D. Clin Endocrinol (Oxf). 1986; 25:373-381. [PubMed: 3040300] 
93. Sakai Y, Demay MB. Evaluation of keratinocyte proliferation and differentiation in vitamin D receptor knockout mice. Endocrinology. 2000; 141:2043-2049. [PubMed: 10830288]

94. Kong J, Li XJ, Gavin D, Jiang Y, Li YC. Targeted expression of human vitamin d receptor in the skin promotes the initiation of the postnatal hair follicle cycle and rescues the alopecia in vitamin D receptor null mice. J Invest Dermatol. 2002; 118:631-638. [PubMed: 11918709]

95. Chen CH, Sakai Y, Demay MB. Targeting expression of the human vitamin D receptor to the keratinocytes of vitamin D receptor null mice prevents alopecia. Endocrinology. 2001; 142:53865389. [PubMed: 11713240]

96. Li YC, Amling M, Pirro AE, Priemel M, Meuse J, Baron R, et al. Normalization of mineral ion homeostasis by dietary means prevents hyperparathyroidism, rickets, and osteomalacia, but not alopecia in vitamin D receptor-ablated mice. Endocrinology. 1998; 139:4391-4396. [PubMed: 9751523]

97. Teichert A, Elalieh H, Bikle D. Role of vitamin D receptor in hair follicle cycling through local expression. J Invest Dermatol. 2011; 131:S1-S141. Abstract \#446.

98. Panteleyev AA, Botchkareva NV, Sundberg JP, Christiano AM, Paus R. The role of the hairless (hr) gene in the regulation of hair follicle catagen transformation. Am J Pathol. 1999; 155:159171. [PubMed: 10393848]

99. Miller J, Djabali K, Chen T, Liu Y, Ioffreda M, Lyle S, et al. Atrichia caused by mutations in the vitamin $\mathrm{D}$ receptor gene is a phenocopy of generalized atrichia caused by mutations in the hairless gene. J Invest Dermatol. 2001; 117:612-617. [PubMed: 11564167]

100. Ahmad W, Faiyaz ul Haque M, Brancolini V, Tsou HC, ul Haque S, Lam H, et al. Alopecia universalis associated with a mutation in the human hairless gene. Science. 1998; 279:720-724. [PubMed: 9445480]

101. Millar SE. Molecular mechanisms regulating hair follicle development. J Invest Dermatol. 2002; 118:216-225. [PubMed: 11841536]

102. Stenn KS, Paus R. Controls of hair follicle cycling. Physiol Rev. 2001; 81:449-494. [PubMed: 11152763]

103. Huelsken J, Vogel R, Erdmann B, Cotsarelis G, Birchmeier W. beta-Catenin controls hair follicle morphogenesis and stem cell differentiation in the skin. Cell. 2001; 105:533-545. [PubMed: 11371349]

104. DasGupta R, Rhee H, Fuchs E. A developmental conundrum: a stabilized form of beta-catenin lacking the transcriptional activation domain triggers features of hair cell fate in epidermal cells and epidermal cell fate in hair follicle cells. J Cell Biol. 2002; 158:331-344. [PubMed: 12135986]

105. Chiang C, Swan RZ, Grachtchouk M, Bolinger M, Litingtung Y, Robertson EK, et al. Essential role for Sonic hedgehog during hair follicle morphogenesis. Dev Biol. 1999; 205:1-9. [PubMed: 9882493]

106. Reddy ST, Andl T, Lu MM, Morrisey EE, Millar SE. Expression of Frizzled genes in developing and postnatal hair follicles. J Invest Dermatol. 2004; 123:275-282. [PubMed: 15245425]

107. Luderer HF, Gori F, Demay MB. Lymphoid enhancer-binding factor-1 (LEF1) interacts the DNA-binding domain of the vitamin D receptor. J Biol Chem. 2011; 286:18444-18451. [PubMed: 21471213]

108. Greenlee RT, Hill-Harmon MB, Murray T, Thun M. Cancer statistics, 2001. CA Cancer J Clin. 2001; 51:15-36. [PubMed: 11577478]

109. Freeman SE, Hacham H, Gange RW, Maytum DJ, Sutherland JC, Sutherland BM. Wavelength dependence of pyrimidine dimer formation in DNA of human skin irradiated in situ with ultraviolet light. Proc Natl Acad Sci USA. 1989; 86:5605-5609. [PubMed: 2748607]

110. Hussein MR. Ultraviolet radiation and skin cancer: molecular mechanisms. J Cutan Pathol. 2005; 32:191-205. [PubMed: 15701081]

111. Daya-Grosjean L, Sarasin A. The role of UV induced lesions in skin carcinogenesis: an overview of oncogene and tumor suppressor gene modifications in xeroderma pigmentosum skin tumors. Mutat Res. 2005; 571:43-56. [PubMed: 15748637] 
112. Ziegler A, Leffell DJ, Kunala S, Sharma HW, Gailani M, Simon JA, et al. Mutation hotspots due to sunlight in the p53 gene of nonmelanoma skin cancers. Proc Natl Acad Sci USA. 1993; 90:4216-4220. [PubMed: 8483937]

113. Ziegler A, Jonason AS, Leffell DJ, Simon JA, Sharma HW, Kimmelman J, et al. Sunburn and p53 in the onset of skin cancer. Nature. 1994; 372:773-776. [PubMed: 7997263]

114. Brash DE, Rudolph JA, Simon JA, Lin A, McKenna GJ, Baden HP, et al. A role for sunlight in skin cancer: UV-induced p53 mutations in squamous cell carcinoma. Proc Natl Acad Sci USA. 1991; 88:10124-10128. [PubMed: 1946433]

115. Bito T, Ueda M, Ahmed NU, Nagano T, Ichihashi M. Cyclin D and retinoblastoma gene product expression in actinic keratosis and cutaneous squamous cell carcinoma in relation to p53 expression. J Cutan Pathol. 1995; 22:427-434. [PubMed: 8594075]

116. Reifenberger J, Wolter M, Knobbe CB, Kohler B, Schonicke A, Scharwachter C, et al. Somatic mutations in the PTCH, SMOH, SUFUH and TP53 genes in sporadic basal cell carcinomas. Br J Dermatol. 2005; 152:43-51. [PubMed: 15656799]

117. Johnson RL, Rothman AL, Xie J, Goodrich LV, Bare JW, Bonifas JM, et al. Human homolog of patched, a candidate gene for the basal cell nevus syndrome. Science. 1996; 272:1668-1671. [PubMed: 8658145]

118. Hahn H, Wicking C, Zaphiropoulous PG, Gailani MR, Shanley S, Chidambaram A, et al. Mutations of the human homolog of Drosophila patched in the nevoid basal cell carcinoma syndrome. Cell. 1996; 85:841-851. [PubMed: 8681379]

119. Aszterbaum M, Rothman A, Johnson RL, Fisher M, Xie J, Bonifas JM, et al. Identification of mutations in the human PATCHED gene in sporadic basal cell carcinomas and in patients with the basal cell nevus syndrome. J Invest Dermatol. 1998; 110:885-888. [PubMed: 9620294]

120. Aszterbaum M, Epstein J, Oro A, Douglas V, LeBoit PE, Scott MP, et al. Ultraviolet and ionizing radiation enhance the growth of BCCs and trichoblastomas in patched heterozygous knockout mice. Nat Med. 1999; 5:1285-1291. [PubMed: 10545995]

121. Ping XL, Ratner D, Zhang H, Wu XL, Zhang MJ, Chen FF, et al. PTCH mutations in squamous cell carcinoma of the skin. J Invest Dermatol. 2001; 116:614-616. [PubMed: 11286632]

122. Grachtchouk M, Pero J, Yang SH, Ermilov AN, Michael LE, Wang A, et al. Basal cell carcinomas in mice arise from hair follicle stem cells and multiple epithelial progenitor populations. J Clin Invest. 2011; 121:1768-1781. [PubMed: 21519145]

123. Zinser GM, Sundberg JP, Welsh J. Vitamin D(3) receptor ablation sensitizes skin to chemically induced tumorigenesis. Carcinogenesis. 2002; 23:2103-2109. [PubMed: 12507934]

124. Indra AK, Castaneda E, Antal MC, Jiang M, Messaddeq N, Meng X, Loehr CV, Gariglio P, Kato S, Wahli W, Desvergne B, Metzger D, Chambon P. Malignant transformation of DMBA/ TPAInduced papillomas and nevi in the skin of mice selectively lacking retinoid-X-receptor alpha in epidermal keratinocytes. J Invest Dermatol. 2007

125. Ellison TI, Smith MK, Gilliam AC, Macdonald PN. Inactivation of the vitamin D receptor enhances susceptibility of murine skin to UVInduced tumorigenesis. J Invest Dermatol. 2008; 128:2508-2517. [PubMed: 18509362]

126. Dixon KM, Deo SS, Wong G, Slater M, Norman AW, Bishop JE, et al. Skin cancer prevention: a possible role of 1,25dihydroxyvitamin D3 and its analogs. J Steroid Biochem Mol Biol. 2005; 97:137-143. [PubMed: 16039116]

127. Gupta R, Dixon KM, Deo SS, Holliday CJ, Slater M, Halliday GM, et al. Photoprotection by 1,25 dihydroxyvitamin D3 is associated with an increase in p53 and a decrease in nitric oxide products. J Invest Dermatol. 2007; 127:707-715. [PubMed: 17170736]

128. De Haes P, Garmyn M, Degreef H, Vantieghem K, Bouillon R, Segaert S. 1,25Dihydroxyvitamin D3 inhibits ultraviolet B-induced apoptosis, Jun kinase activation, and interleukin-6 production in primary human keratinocytes. J Cell Biochem. 2003; 89:663-673. [PubMed: 12858333]

129. Regl G, Kasper M, Schnidar H, Eichberger T, Neill GW, Ikram MS, et al. The zinc-finger transcription factor GLI2 antagonizes contact inhibition and differentiation of human epidermal cells. Oncogene. 2004; 23:1263-1274. [PubMed: 14691458] 
130. Barnfield PC, Zhang X, Thanabalasingham V, Yoshida M, Hui CC. Negative regulation of Gli1 and Gli2 activator function by suppressor of fused through multiple mechanisms. Differentiation. 2005; 73:397-405. [PubMed: 16316410]

131. Wakabayashi Y, Mao JH, Brown K, Girardi M, Balmain A. Promotion of Hras-induced squamous carcinomas by a polymorphic variant of the Patched gene in FVB mice. Nature. 2007; 445:761765. [PubMed: 17230190]

132. Bijlsma MF, Spek CA, Zivkovic D, van de Water S, Rezaee F, Peppelenbosch MP. Repression of smoothened by patched-dependent (pro-)vitamin D3 secretion. PLoS Biol. 2006; 4:e232. [PubMed: 16895439]

133. Tang JY, Xiao TZ, Oda Y, Chang KS, Shpall E, Wu A, et al. Vitamin D3 inhibits hedgehog signaling and proliferation in murine Basal cell carcinomas. Canc Prev Res (Philadelphia, Pa). 2011; 4:744-751.

134. Svard J, Heby-Henricson K, Persson-Lek M, Rozell B, Lauth M, Bergstrom A, et al. Genetic elimination of Suppressor of fused reveals an essential repressor function in the mammalian Hedgehog signaling pathway. Dev Cell. 2006; 10:187-197. [PubMed: 16459298]

135. Regl G, Kasper M, Schnidar H, Eichberger T, Neill GW, Philpott MP, et al. Activation of the BCL2 promoter in response to Hedgehog/GLI signal transduction is predominantly mediated by GLI2. Cancer Res. 2004; 64:7724-7731. [PubMed: 15520176]

136. Regl G, Neill GW, Eichberger T, Kasper M, Ikram MS, Koller J, et al. Human GLI2 and GLI1 are part of a positive feedback mechanism in Basal Cell Carcinoma. Oncogene. 2002; 21:55295539. [PubMed: 12165851]

137. Grachtchouk M, Mo R, Yu S, Zhang X, Sasaki H, Hui CC, et al. Basal cell carcinomas in mice overexpressing Gli2 in skin. Nat Genet. 2000; 24:216-217. [PubMed: 10700170]

138. Nilsson M, Unden AB, Krause D, Malmqwist U, Raza K, Zaphiropoulos PG, et al. Induction of basal cell carcinomas and trichoepitheliomas in mice overexpressing GLI-1. Proc Natl Acad Sci USA. 2000; 97:3438-3443. [PubMed: 10725363]

139. Oro AE, Higgins KM, Hu Z, Bonifas JM, Epstein EH Jr, Scott MP. Basal cell carcinomas in mice overexpressing sonic hedgehog. Science. 1997; 276:817-821. [PubMed: 9115210]

140. Fan H, Oro AE, Scott MP, Khavari PA. Induction of basal cell carcinoma features in transgenic human skin expressing Sonic Hedgehog. Nat Med. 1997; 3:788-792. [PubMed: 9212109]

141. Tojo M, Mori T, Kiyosawa H, Honma Y, Tanno Y, Kanazawa KY, et al. Expression of sonic hedgehog signal transducers, patched and smoothened, in human basal cell carcinoma. Pathol Int. 1999; 49:687-694. [PubMed: 10504535]

142. Bonifas JM, Pennypacker S, Chuang PT, McMahon AP, Williams M, Rosenthal A, et al. Activation of expression of hedgehog target genes in basal cell carcinomas. J Invest Dermatol. 2001; 116:739-742. [PubMed: 11348463]

143. Eichberger T, Regl G, Ikram MS, Neill GW, Philpott MP, Aberger F, et al. FOXE1, a new transcriptional target of GLI2 is expressed in human epidermis and basal cell carcinoma. J Invest Dermatol. 2004; 122:1180-1187. [PubMed: 15140221]

144. Wang TT, Tavera-Mendoza LE, Laperriere D, Libby E, MacLeod NB, Nagai Y, et al. Large-scale in silico and microarray-based identification of direct 1,25-dihydroxyvitamin D3 target genes. Mol Endocrinol. 2005; 19:2685-2695. [PubMed: 16002434]

145. Saldanha G, Ghura V, Potter L, Fletcher A. Nuclear beta-catenin in basal cell carcinoma correlates with increased proliferation. Br J Dermatol. 2004; 151:157-164. [PubMed: 15270885]

146. Iwatsuki K, Liu HX, Gronder A, Singer MA, Lane TF, Grosschedl R, et al. Wnt signaling interacts with Shh to regulate taste papilla development. Proc Natl Acad Sci USA. 2007; 104:2253-2258. [PubMed: 17284610] 


\title{
Coactivators VDR Function Target genes
}
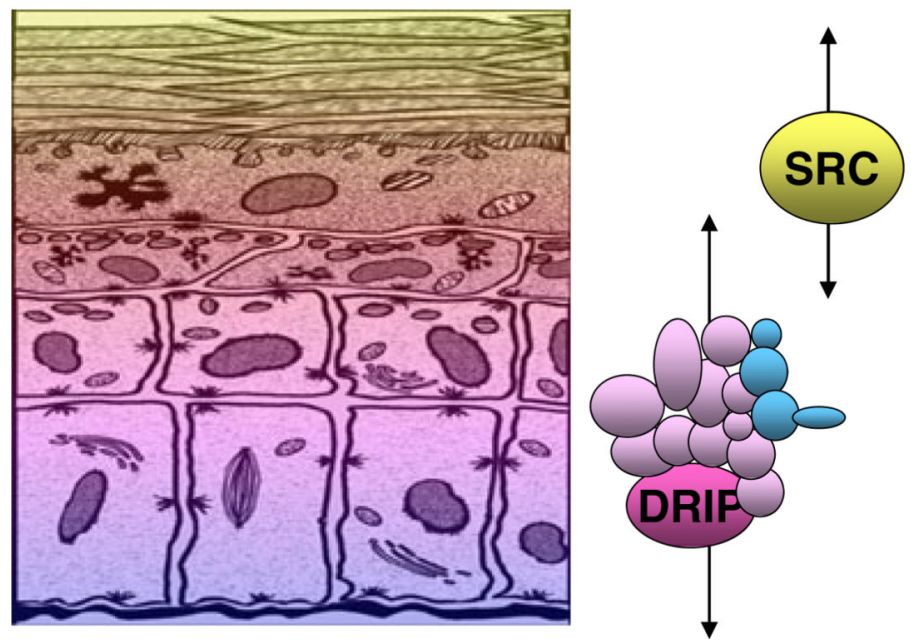

\author{
Barrier formation \\ Innate Immunity
}

ABCA12, UGCG, ELOVL4

Cathelicidin, CD14

Epidermal Differentiation K1, K10, FLG, LOR

Hair Differentiation

Hair keratins

Proliferation

Cyclin D1, Gli 1

Wnt signaling

Fig. 1.

The different layers of the epidermis, and the functions within those layers regulated by VDR and its coactivators. The basal layer of the epidermis (stratum basale) contains the stem cells that through proliferation provide the cells for the upper layers. As the keratinocytes leave the basal layer differentiation takes place with $\mathrm{K} 1, \mathrm{~K} 10$, involucrin, and transglutaminase being expressed in the stratum spinosum, filaggrin and loricrin being expressed in the stratum granulosum. Lamellar bodies forming in the stratum granulosum inject their lipid content into the intercellular spaces between the stratum granulosum and stratum corneum to provide the water proofing for the permeability barrier. DRIP205 is most highly expressed in the stratum basale and spinosum where it participates with VDR in regulating proliferation in partnership with the wnt/ $\beta$-catenin signaling pathway. Cyclin D1 and Gli 1 (a transcriptional factor for the hedgehog pathway) are regulated by VDR, DRIP205, and $\beta$-catenin. SRC3 on the other hand is found in highest concentration in the stratum granulosum where it participates with VDR in the regulation of terminal differentiation. SRC3 is critical for lipid processing and lamellar body formation required for formation of the permeability barrier as well as $1,25(\mathrm{OH})_{2} \mathrm{D}$ induction of cathelicidin and CD14 required for innate immunity 


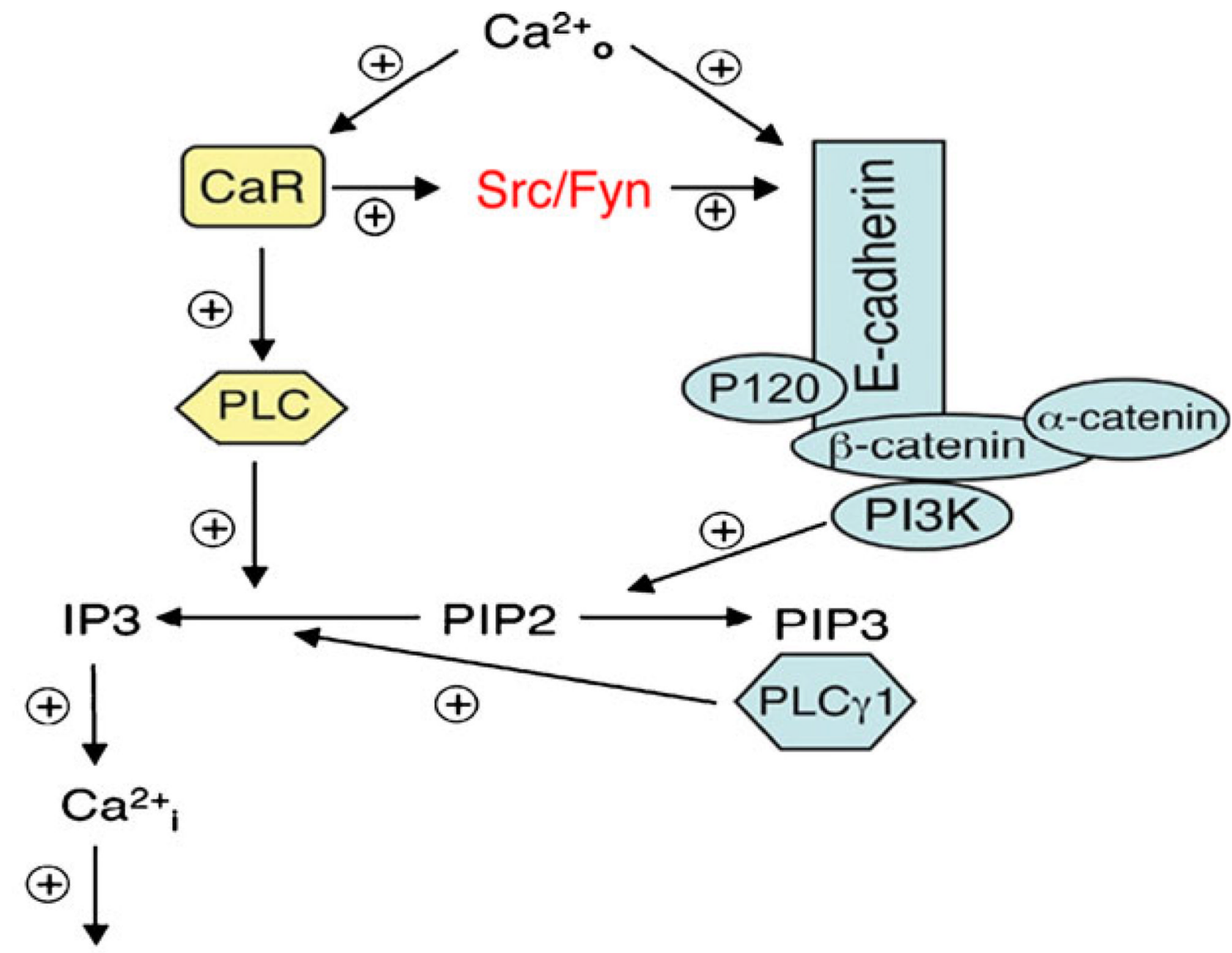

\section{Differentiation}

Fig. 2.

Calcium signaling in keratinocytes. Extracellular calcium (Cao) leads to the formation of the E-cadherin/catenin complex directly and through the $\mathrm{CaR}$, events critical for the ability of Cao to induce keratinocyte differentiation. When the $\mathrm{CaR}$ is activated by Cao it activates the src kinase family members src and fyn, which in turn phosphorylate the various catenins (p120, $\beta$-catenin, $\alpha$-catenin) enabling them to complex with E-cadherin. P120 is required for the stability of the E-cadherin complex in the membrane, a-catenin links the complex to the underlying cytoskeleton, and $\beta$-catenin binds phosphatidyl inositol 3 kinase (PI3K) and phosphatidyl inositol phosphate 5 kinase $1 a$ (PIP5K1 a (not shown). These latter enzymes are responsible for maintaining adequate levels of PIP3 in the membrane, which is the key molecule for activating PLC $\gamma 1$ following Cao administration. CaR also activates PLC $\beta$, and both PLC $\gamma 1$ and PLC $\beta$ hydrolyze PIP2 to form IP3 and diacylglycerol (DG) (not shown). DG activates PKC (not shown), whereas IP3 releases calcium from intracellular stores (Cai). The rise in Cai leads to the induction of genes critical for the differentiation process 


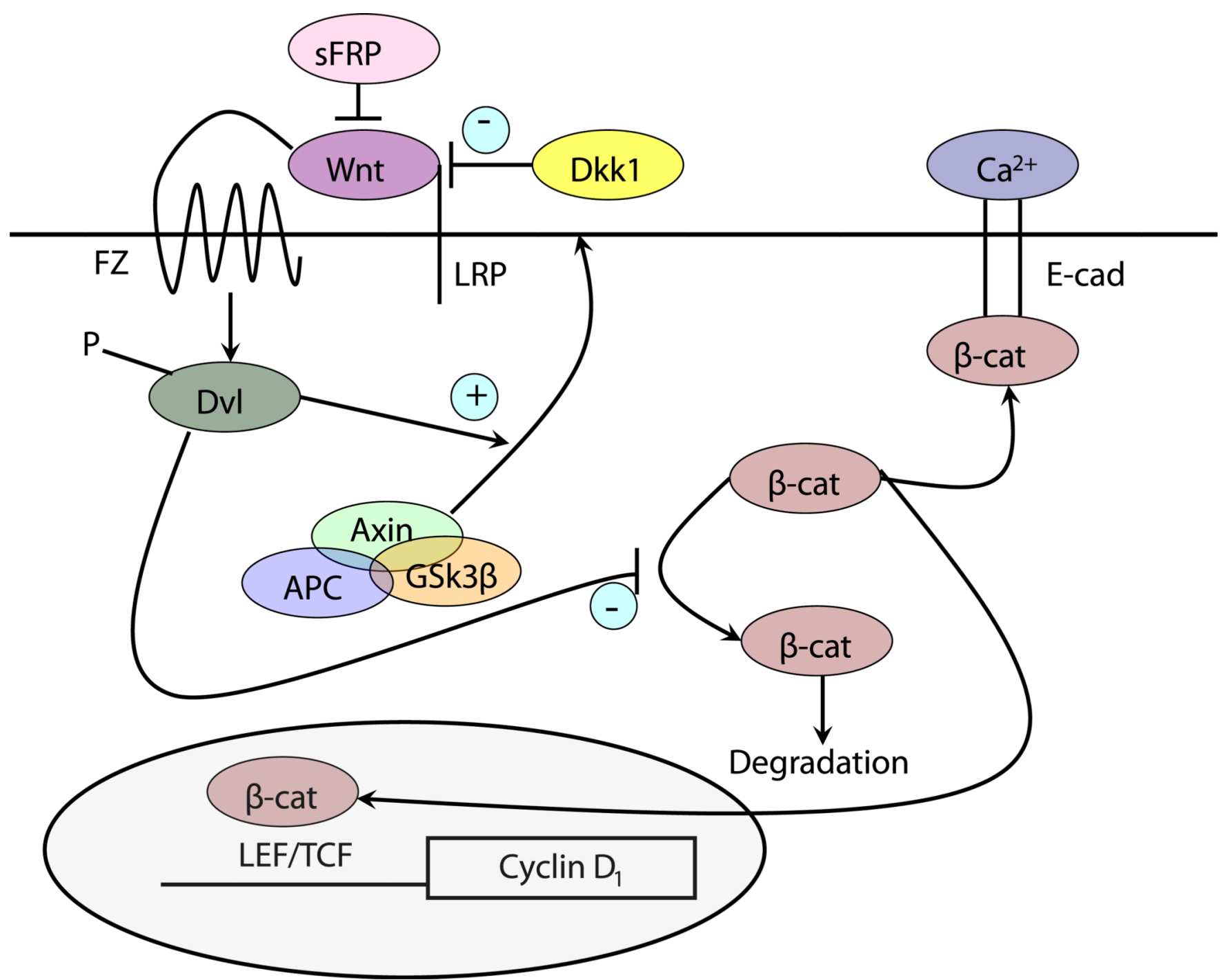

Fig. 3.

The canonical wnt signaling pathway. Wnts bind to their frizzled receptors (FZ) and coreceptors LRP in the membrane. This binding can be blocked by dickkopf (Dkk) or soluble frizzled related proteins (sFRP). Activation of FZ by wnt results in phosphorylation of disheveled (Dvl), which induces the disruption of the axin/APC/ GSK-3 $\beta$ complex and recruitment of axin to the membrane. This complex when active phosphorylates $\beta$-catenin, leading to its proteosomal degradation. However, following wnt stimulation $\beta$-catenin is no longer degraded and can enter the nucleus where in combination with members of the LEF/ TCF family can induce expression of its target genes such as cyclin D1. $\beta$-catenin also binds to the E-cadherin complex in the plasma membrane, a complex stabilized by calcium and induced by $1,25(\mathrm{OH})_{2} \mathrm{D}$ 


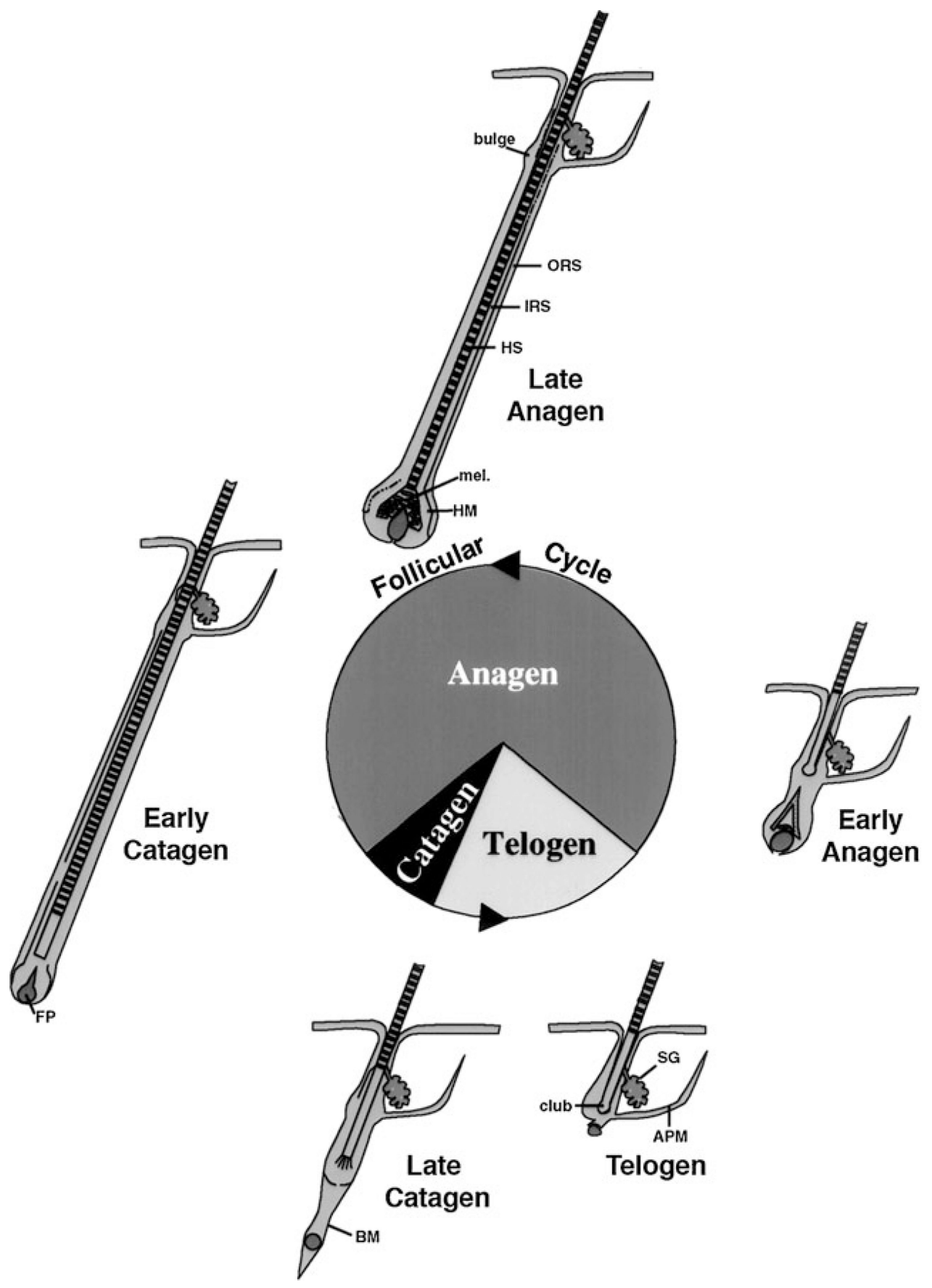

Fig. 4.

Hair follicle cycling. The initial developmental phase of hair follicle development terminates with catagen and the first telogen, after which repetitive cycles of anagen (the growth phase), catagen (the regression phase), and telogen (the resting phase) occur throughout the life span of the animal. In general the hair follicle spends most of its time in anagen. But cycle duration varies according to location, gender, age, species. The bulge is the source of stem cells for the regenerating hair follicle, responding to signals from the dermal or follicular papilla (FP). ORS: outer root sheath, IRS: inner root sheath, HS: hair shaft, mel: melanin for the hair shaft, HM: hair matrix, BM: basement membrane, SG: sebaceous gland, APM: arrector pili muscle 


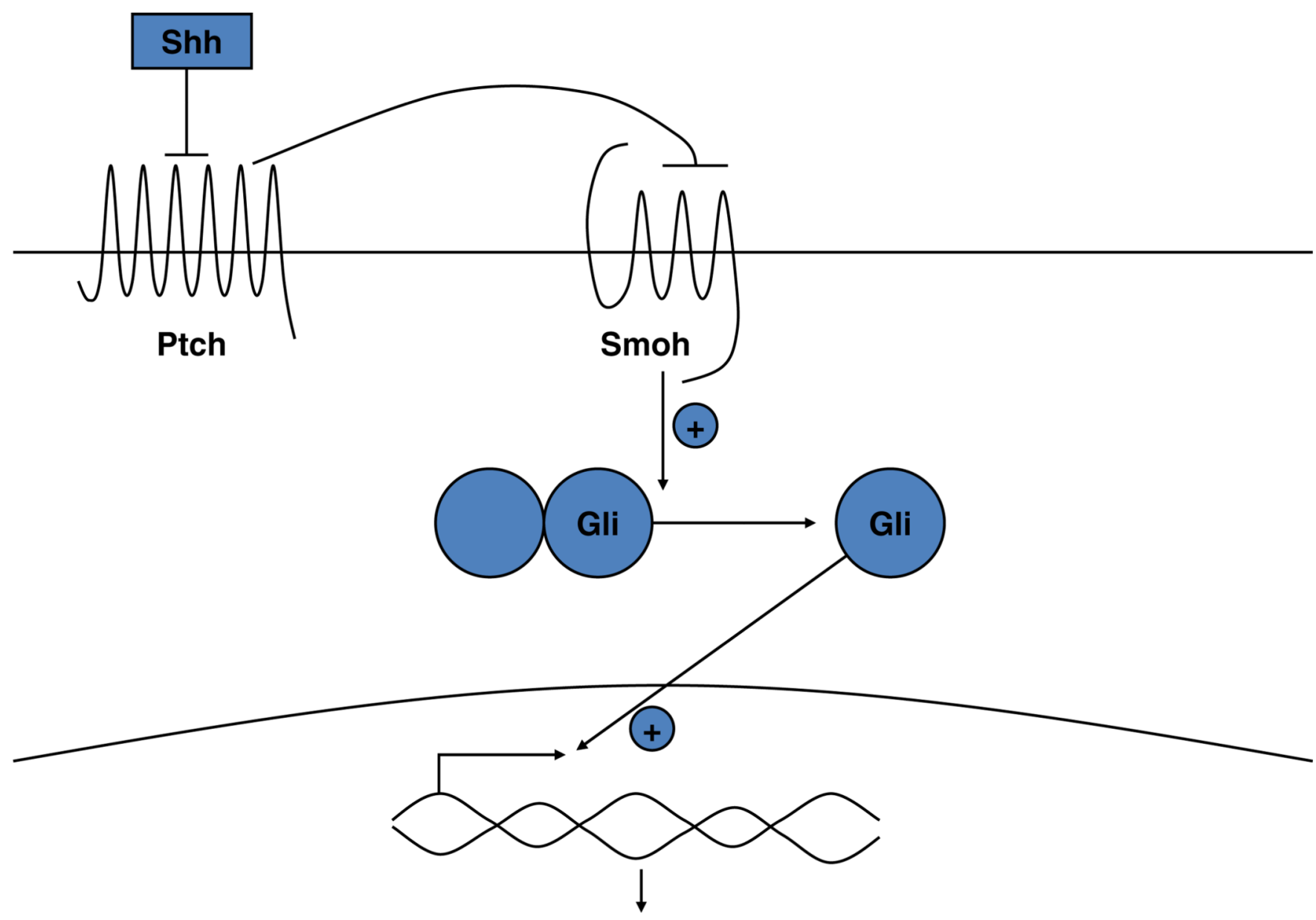

Fig. 5.

The Sonic hedgehog (Shh) signaling pathway. In the absence of Shh, Ptch 1 suppresses signaling by smoothened (Smoh). Binding of Shh to Ptch 1 relieves this inhibition.

Activation of Smoh leads to the activation and translocation of transcription factors of the Gli family into the nucleus, with subsequent changes in gene expression 


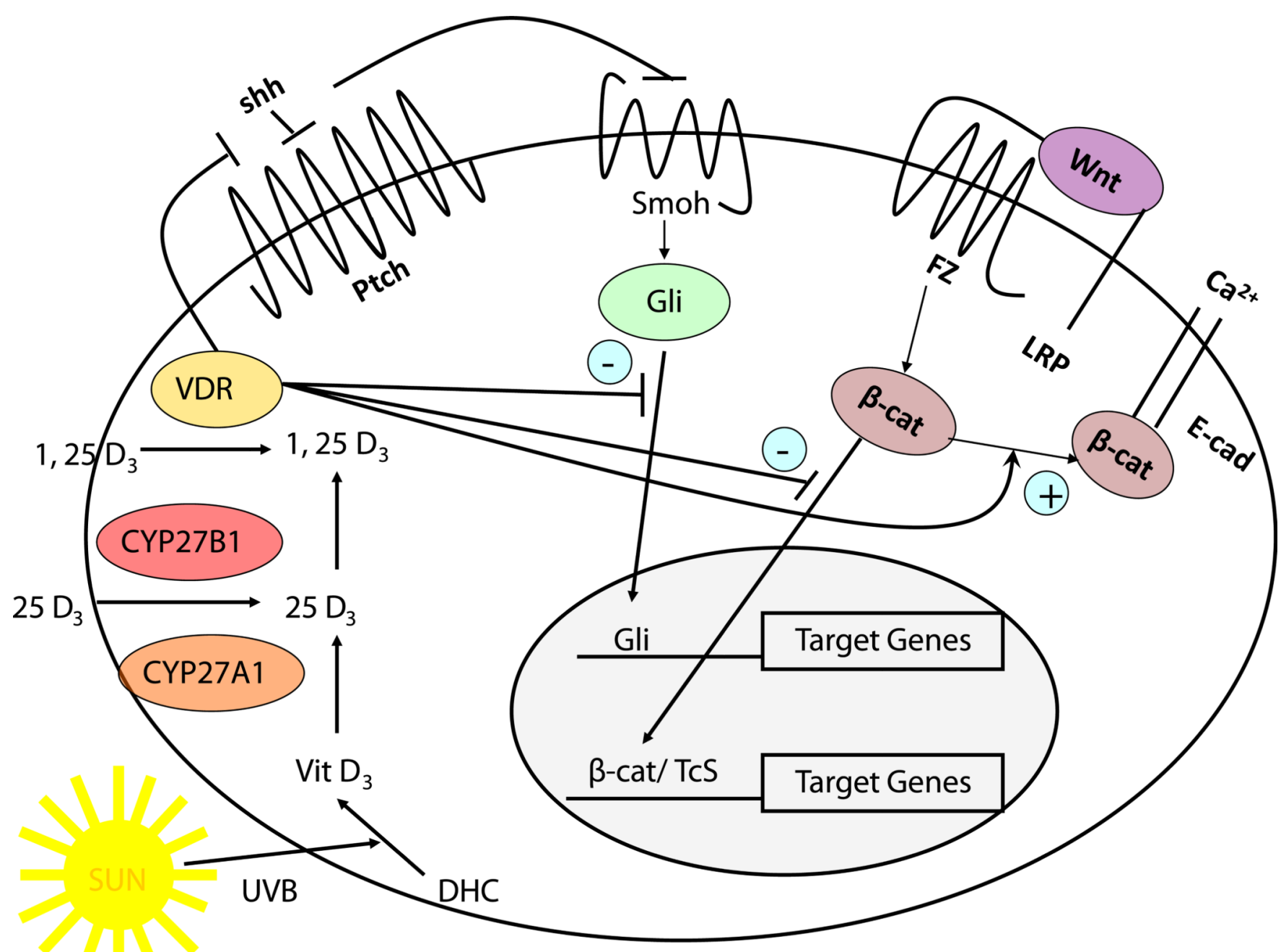

Fig. 6.

Working model for the regulation of $\mathrm{Hh}$ and $\beta$-catenin signaling in keratinocytes by $1,25(\mathrm{OH})_{2} \mathrm{D}$ and VDR. The keratinocyte is capable of making its own $1,25(\mathrm{OH})_{2} \mathrm{D}$ from the vitamin D produced from 7-dehydrocholesterol (DHC) under the influence of UVB, as it has both CYP27A1 (which converts vitamin D to 25OHD) and CYP27b1 (which converts $25 \mathrm{OHD}$ to $\left.1,25(\mathrm{OH})_{2} \mathrm{D}\right)$. However, both $25 \mathrm{OHD}$ and $1,25(\mathrm{OH})_{2} \mathrm{D}$ are also available from the circulation. The VDR with or without its ligand suppresses Shh expression, may have a direct inhibitory action on Gli transcriptional activity (postulated, not demonstrated), binds $\beta$-catenin and induces E-cadherin expression reducing the amount of $\beta$-catenin available for binding to LEF1. However, VDR may promote the transcriptional activity of $\beta$-catenin in a ligand independent fashion at least in hair follicle keratinocytes. These actions regulate transcriptional activity of both gli and $\beta$-catenin 